\title{
Fused Tricyclic Phosphiranes-Analysis of Phosphorus Chemical Shieldings
}

\author{
Erik P. A. Couzijn, ${ }^{[a]}$ Andreas W. Ehlers, ${ }^{[a]}$ J. Chris Slootweg, ${ }^{[a]}$ Marius Schakel, ${ }^{[a]}$ \\ Steffen Krill, ${ }^{[b]}$ Martin Lutz, ${ }^{[c]}$ Anthony L. Spek, ${ }^{[c]}$ and Koop Lammertsma*[a, b]
}

\begin{abstract}
Addition of transient $\mathrm{W}(\mathrm{CO})_{5}$-complexed phosphinidenes exo to hexamethyl Dewar benzene affords the novel 3-phosphatricyclo[3.2.0.0 $\left.0^{2,4}\right]$ hept-6-ene complexes. The fused tricyclic phosphiranes are obtained as both the $Z$ and the thermally less stable $E$ isomers, the ${ }^{31} \mathrm{P}$ NMR chemical shifts of which differ by about
\end{abstract}

$60 \mathrm{ppm}$. A computational investigation shows that the phosphorus pyramidalization and the presence of the $\gamma$

Keywords: density functional calculations $\cdot$ fused-ring systems $\cdot$ NMR spectroscopy $\cdot$ phosphorus heterocycles $\cdot$ ring strain double bond are responsible for this effect. The semiquantitative results contribute to a more systematic understanding of the structural influences on ${ }^{31} \mathrm{P}$ chemical shieldings. The congested double bond of the $Z$ isomer can be epoxidized with $m$-chloroperbenzoic acid (MCPBA) to afford a fused tetracyclic $\mathrm{P}, \mathrm{O}$ bis-adduct.

\section{Introduction}

Organophosphorus compounds constitute the largest ligand class for catalysis. Probing the ligand properties by ${ }^{31} \mathrm{P}$ NMR spectroscopy would be highly desirable, but studies show only moderate or even counterintuitive relationships. ${ }^{[1,2]}$ Phosphorus nuclear chemical shifts are governed by several factors, such as resonance interactions, inductive and steric effects, bond angles, and ring size. ${ }^{[2-4]}$ Even the structurally very similar $Z$ and $E$ isomers of 7-phosphanorbornenes 1 differ by as much as $70 \mathrm{ppm}$ in ${ }^{31} \mathrm{P}$ NMR chemical shifts. ${ }^{[3]}$ The advance of computing capacity allows for theoretical analyses of experimental systems. ${ }^{[2 a, 4,5]}$ Chesnut et al. ${ }^{[4]}$ relat-

[a] E. P. A. Couzijn, Dr. A. W. Ehlers, Dr. J. C. Slootweg,

Dr. M. Schakel, Prof. Dr. K. Lammertsma

Department of Organic Chemistry

Faculty of Sciences, Vrije Universiteit

De Boelelaan 1083, 1081 HV, Amsterdam (The Netherlands)

Fax: (+31) 20-598-7488

E-mail: K.Lammertsma@few.vu.nl

[b] Dr. S. Krill, Prof. Dr. K. Lammertsma

Formerly associated with the Department of Chemistry

University of Alabama at Birmingham

Birmingham, AL 35294 (USA)

[c] Dr. M. Lutz, Prof. Dr. A. L. Spek

Crystal and Structural Chemistry

Bijvoet Center for Biomolecular Research

Utrecht University

Padualaan 8, 3584 CH Utrecht (The Netherlands)

Supporting information for this article is available on the WWW

under http://www.chemeurj.org/ or from the author.

ed the variations in shielding to the magnitude of the HOMOLUMO energy gap $E_{\mathrm{g}}$ and addressed the underlying principles to qualitatively account for the variations, but noted that nonadditive $\alpha$-, $\beta$-, and $\gamma$-substituent effects dominate the overall shielding.

The 1,2-addition of carbene-like electrophilic phosphinidenes to alkenes gives direct access to both the $Z$ and $E$ isomeric phosphiranes, ${ }^{[6-9]}$ providing suitable test systems for ${ }^{31} \mathrm{P}$ NMR analysis. For example, the isomers of strained phosphiranes $\mathbf{2}^{[7]}$ and $\mathbf{3}^{[8]}$ show a difference in ${ }^{31} \mathrm{P}$ chemical shielding analogous to $\mathbf{1}$. Here, we report on phosphinidene addition to hexamethyl Dewar benzene (9) to give the novel
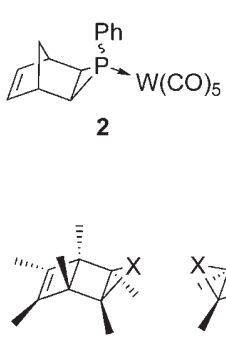

5a: $\mathrm{X}=\mathrm{CH}_{2}$

b: $X=O$

c: $X=S^{+} P h$<smiles>O=[N+]([O-])C1CC2CCC(C1c1ccccc1)P2c1ccccc1</smiles>

3

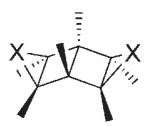

6a: $\mathrm{X}=\mathrm{CH}_{2}$

b: $X=0$

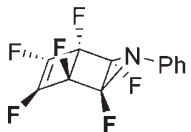

7

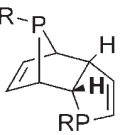

(Z)-1a: $R=P h$ b: $R=M e$

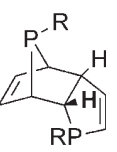

(E)-1a,b \section{列}


exo-annellated phosphiranes 4 , which have been characterized by NMR spectroscopy and X-ray crystallography. Also, the $Z$ and $E$ isomers of $\mathbf{4}$ have remarkably different ${ }^{31} \mathrm{P}$ NMR chemical shifts. We explain the origins of this phenomenon semiquantitatively by a computational investigation, providing a more systematic understanding of structural influences on the ${ }^{31} \mathrm{P}$ chemical shift.

Furthermore, adducts on hexamethyl Dewar benzene are scarce and, to the best of our knowledge, the phosphiranes 4 are the first isolated second-row element 1,2-adducts of $\mathbf{9}$. First-row elements in mono- and bis-adducts of 9 are known, such as $\mathbf{5} \mathbf{a}, \mathbf{b}$ and $\mathbf{6},{ }^{[10,11]}$ as are the nitrene adducts of hexafluoro Dewar benzene (7 and 8), ${ }^{[12]}$ but only for $\mathbf{6 b}$ has a crystal structure been reported. ${ }^{[11 \mathrm{~b}]}$ The intermediacy of the cationic sulfur analogue $\mathbf{5} \mathbf{c}$ has been proposed, but it decomposes at $-60^{\circ} \mathrm{C} .{ }^{[13]}$ Therefore, we also report on the strain in $\mathbf{4}$ as well as on the reactivity of the remaining double bond in these fused tricyclic systems.

\section{Results and Discussion}

Synthesis: Benzophosphepines $\mathbf{1 0}$ were recently developed, ${ }^{[14]}$ from which transient terminal phosphinidene complexes $\left[\mathrm{RP}=\mathrm{W}(\mathrm{CO})_{5}\right]$ were generated in situ under mild conditions $\left(10 \mathrm{a}: \mathrm{R}=\right.$ phenyl, $\left.\geq 55^{\circ} \mathrm{C} ; \mathbf{b}: \mathrm{R}=\mathrm{Me}, \geq 65^{\circ} \mathrm{C}\right)$ by cheletropic elimination of naphthalene from the phosphanorcaradiene intermediate. Reaction of $\mathbf{1 0} \mathbf{a}, \mathbf{b}$ with 9 in toluene cleanly afforded the annellated phosphiranes $\mathbf{4 a}$ and $\mathbf{4 b}$ in 60 and $66 \%$ isolated yield, respectively (Scheme 1). ${ }^{[15]}$

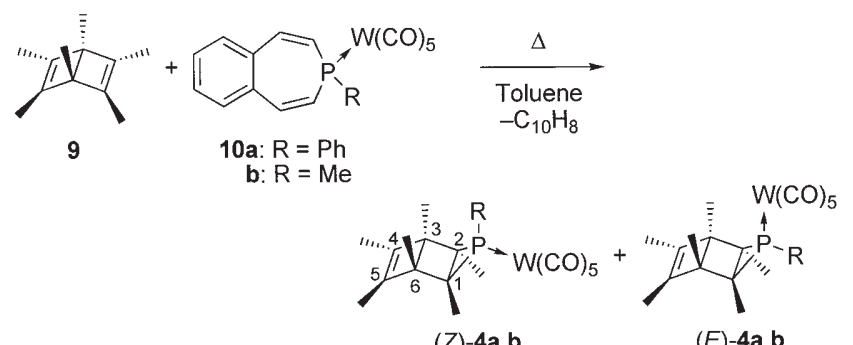

Scheme 1. Synthetic route to tricyclic phosphiranes $\mathbf{4}$, including ring atom numbering.

Isomer (Z)-4a could be separated from the $E$ isomer and purified by column chromatography and fractional crystallization to give a white crystalline solid that decomposes above $145^{\circ} \mathrm{C} ; \mathbf{4} \mathbf{b}$ could only be partially separated into isomerically enriched fractions.

NMR analysis of the products suggested that the phosphinidene complex has added exo to the double bond, while the phosphorus substituent $\mathrm{R}$ is oriented either $Z$ or $E$ with respect to the central cyclobutane moiety. For example, the 2D NOESY spectra for both isomers of $\mathbf{4 a}$ feature an interaction of the phosphirane methyl (Me) groups (at $\mathrm{C} 1 / 2$ ) with those attached to the double bond, which would be absent in the endo adducts $\mathbf{1 1 a}$. Furthermore, correlations are observed for the phenyl ortho-H atoms with the central methyl groups (at $\mathrm{C} 3 / 6$ ) of the $Z$ isomer and with the methyl groups of the phosphirane moiety (at $\mathrm{C} 1 / 2$ ) of the $E$ isomer. The preference for the exo isomers is consistent with the addition of other heteroatom groups that lead to the exo adducts 5 and $\mathbf{6}^{[10,11]}$ and with the addition of $[\mathrm{RP}=$ $\left.\mathrm{W}(\mathrm{CO})_{5}\right]$ to norbornene and related compounds. ${ }^{[16]}$ This preference for exo addition has been attributed to rehybridization of the double bond(s) in the substrate, which causes a tilting of the $\mathrm{p}$ atomic orbitals of the carbon atom. ${ }^{[16 \mathrm{~b}]}$ As a result, the HOMO $\pi$ electron density is more localized on the exo face than on the endo face, as illustrated for 9 in Figure 1.

The ${ }^{31} \mathrm{P}$ NMR chemical shifts

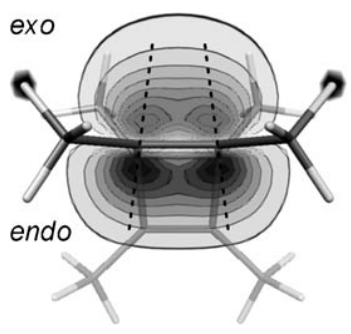

Figure 1. HOMO electron density distribution in 9. of the products $(4 \mathbf{a}:-63.0(Z)$, $-126.9(E) ; \mathbf{4 b}:-87.3(Z),-138.5 \mathrm{ppm}(E))$ are similar to those of the related norbornadiene adducts $2(-61.0(Z)$, $-100.7 \mathrm{ppm}(E)),{ }^{[7]}$ but are significantly deshielded relative to the parent phosphirane complexes 12a $(-187.6 \mathrm{ppm})^{[17]}$ and 12b $(-199.3 \mathrm{ppm}$, see below ${ }^{[18]}$ The phosphirane carbon atoms resonate at rather low field (e.g. (Z)-4a: 49.3 vs. (Z)-2: $35.8 \mathrm{ppm}){ }^{[7]}$

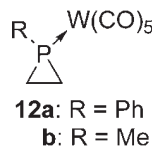

Crystal structure: The geometry

of (Z)-4a was confirmed by X-ray crystallography (Figure 2). The crystal structure shows that the plane of the phenyl ring is parallel to the phosphirane $\mathrm{C}-\mathrm{C}$ bond. This $\mathrm{C} 1-\mathrm{C} 2$ bond length of 1.592(4) $\AA$ is elongated in comparison to those in typical phosphiranes $(1.47-1.52 \AA)^{[7,17 b, 19]}$ and is even longer than those in phosphabicyclobutane $(Z)-3$ $(1.550 \AA) .{ }^{[8]}$ The C3-C6 bridgehead bond is also elongated (1.588(4) $\AA$ ), which is, however, common for cyclobutenes. ${ }^{[20]}$ The central four-membered ring is planar and has interplanar angles of $118.57(19)$ and $110.22(19)^{\circ}$ with the phosphirane and cyclobutene rings, respectively. ${ }^{[21]}$ The central methyl groups (C9 and $\mathrm{C} 12$ ) are bent away from the phenyl group, as designated by the obtuse interplanar angle of $130.4(2)^{\circ}$ with the central cyclobutane versus $119.3(2)^{\circ}$ with the cyclobutene ring. ${ }^{[1]}$

Calculated ${ }^{31} \mathbf{P}$ NMR chemical shifts: Because the ${ }^{1} \mathrm{H}$ NMR resonances of the PMe group of $\mathbf{4 b}$ and those of either its vinylic $(Z)$ or phosphirane methyl groups $(E)$ are in close proximity, the stereochemical assignment by 2D NOESY NMR is not unequivocal. Therefore, we calculated the phosphorus chemical shieldings $\sigma_{\text {calcd }}$ of the four possible adducts 


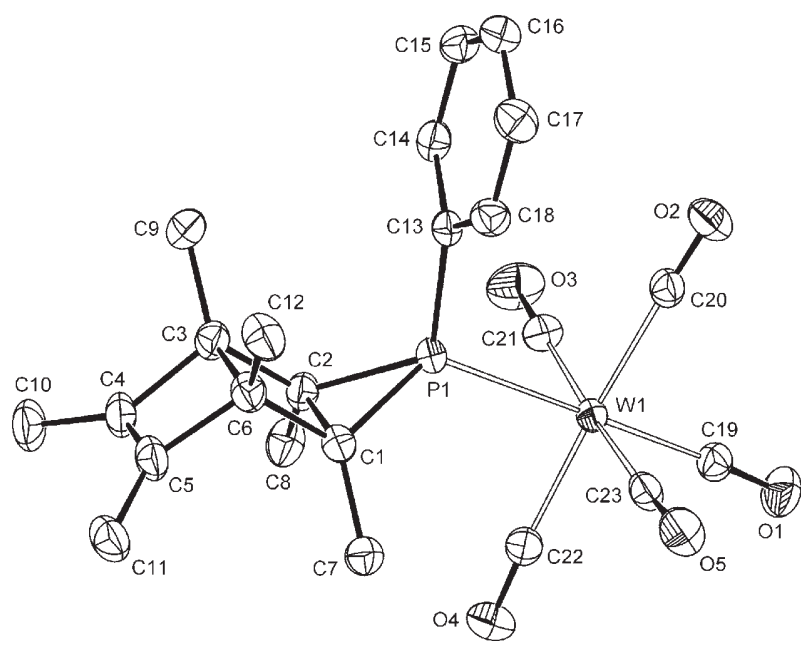

Figure 2. Displacement ellipsoid plot (50\% probability) of $(Z)-\mathbf{4 a}$. Hydrogen atoms are omitted for clarity. Selected bond lengths $(\AA)$, angles and torsion angles $\left({ }^{\circ}\right)$ : W1-P1 2.5206(7), P1-C1 1.831(3), P1-C2 1.840(3), C1-C2 1.592(4), C3-C6 1.588(4), C4-C5 1.334(4), C1-P1-C2 51.41(11), C2-C1-C7 127.1(2), C1-C2-C8 127.9(2), C3-C6-C12 125.6(2), C6-C3-C9 127.1(2), C5-C4-C10 135.1(3), C4-C5-C11 135.3(3), P1-C1-C2-C3 -118.68(16), P1-C2-C1-C6 118.46(16), C1-C6-C3-C4 110.15(19), C2-C3C6-C5 -110.3(2), C1-C6-C3-C9 -130.7(3), C2-C3-C6-C12 130.2(3), C4C3-C6-C12 -119.4(3), C5-C6-C3-C9 119.2(3).

(exolendo, $Z / E$ ) with the Amsterdam Density Functional (ADF) program ${ }^{[22]}$ at the BP86/TZP level of theory to confirm the stereochemistry of the products. The data in

Table 1. BP86/TZP ${ }^{31} \mathrm{P}$ NMR chemical shieldings $\sigma$ and chemical shifts $\delta$ [ppm].

\begin{tabular}{lllll}
\hline & & $\sigma_{\text {calcd }}$ & $\delta_{\text {calcd }}$ & $\delta_{\text {exptl }}$ \\
\hline $\mathbf{1 2 b}$ & & 456.4 & $-199.3^{[\mathrm{a}]}$ & -199.3 \\
$\mathbf{4 a}$ & $Z$ & 318.8 & -61.7 & -63.0 \\
& $E$ & 387.1 & -130.0 & -126.9 \\
$\mathbf{4 b}$ & $Z$ & 338.9 & -81.8 & -87.3 \\
& $E$ & 393.9 & -136.8 & -138.5 \\
$\mathbf{1 1 b}$ & $Z$ & 358.7 & -101.6 & \\
& $E$ & 417.2 & -160.1 &
\end{tabular}

[a] Used as reference chemical shift (see Experimental Section).

Table 1 show an excellent agreement between the computed and experimentally observed NMR chemical shifts of the exo adducts $\mathbf{4 a , b}$ (e.g. (Z)-4b: $\delta=-81.8$ (exptl), $-87.3 \mathrm{ppm}$ (calcd); $(E)-\mathbf{4 b}: \delta=-138.5$ (exptl), $-136.8 \mathrm{ppm}$ (calcd)), while the $Z$ - and E-endo adducts $\mathbf{1 1} \mathbf{b}$ were predicted to be about 20 ppm more shielded as compared to $\mathbf{4} \mathbf{b}$.

Phosphorus chemical shielding differences: The $Z$ isomers of $4 \mathbf{a}$ and $4 \mathbf{b}$ are as much as $\approx 60 \mathrm{ppm}$ less shielded than the $E$ isomers. Similar shielding differences between the $Z$ and $E$ isomers have been observed for the phosphinidene adducts $2,{ }^{[7]}$ phosphabicyclobutanes $\mathbf{3},{ }^{[8]}$ and 7-phosphanorbornenes $1 .^{[3]}$ Next, we examined whether this difference has a sterical or electronic origin.
Phosphorus chemical shielding analysis: Chesnut et al. related the variations in shielding to the magnitude of the HOMO-LUMO energy gap $E_{\mathrm{g}}$ and discussed the underlying principles. ${ }^{[4]}$ They found that of the total shielding the diamagnetic term $\sigma_{\text {Dia }}$ varies little, as it relates to core terms that are similar for all phosphorus compounds, while the paramagnetic component $\sigma_{\text {Para }}$ varies much more. For uncomplexed phosphines, the HOMO represents the lone pair on the phosphorus, while the LUMO resembles an empty phosphorus p-orbital perpendicular to it. In an external magnetic field, effective coupling occurs between these molecular orbitals (MO), ${ }^{[23]}$ and as the LUMO has a nodal plane through the phosphorus, this will cause a paramagnetic deshielding of the nucleus. A smaller energy gap $E_{\mathrm{g}}$ leads to stronger MO coupling and, therefore, to a more negative $\sigma_{\text {Para }}$ The double bond in $\mathbf{1}$ has a large influence on the ${ }^{31} \mathrm{P}$ chemical shielding by raising the HOMO, especially for the $(Z)-\mathbf{1}$ isomer that has its lone pair on the opposite side. ${ }^{[4 a]}$ In the tricyclic phosphiranes $\mathbf{4}$, the double bond is more distant than in 1 (i.e., in the $\gamma$ instead of the $\beta$ position) and, therefore, we would expect a smaller effect.

The HOMO-LUMO gap is also influenced by the valence angles on phosphorus. ${ }^{[4]}$ Due to the steric requirements of the bridgehead methyl groups in $\mathbf{4}$ (relative to 1,3 diaxial steric interactions in cyclohexanes), the phosphorus atom is less pyramidal in the $Z$ than in the $E$ isomer according to our BP86/TZP calculations (i.e., the sum of the C-P-C angles: $279.2(Z)$ and $\left.254.7^{\circ}(E)\right)$. To address this relationship for phosphiranes, we calculated the ${ }^{31} \mathrm{P}$ NMR shieldings for uncomplexed phosphirane $\mathbf{1 2} \mathbf{b}^{\prime}$ (' indicates no $\mathrm{W}(\mathrm{CO})_{5}$ ), while varying the angle $\alpha$ between the $\mathrm{P}-\mathrm{Me}$ bond and the phosphirane plane. The energy required for such deformations is modest, for example, $+2.0 \mathrm{kcal} \mathrm{mol}^{-1}$ for a $10^{\circ} \mathrm{in}-$ crease from the equilibrium value of $101.32^{\circ}$ (see Figure $3 \mathrm{a}$ ). Within the $20^{\circ}$ range of $\alpha$ studied, the shielding changes more than $70 \mathrm{ppm}$ (Figure 3a), which is fully attributable to $\sigma_{\text {Para }}$ and which is paralleled by a change in the HOMOLUMO gap of $0.45 \mathrm{eV}$ (Figure $3 \mathrm{~b}, E_{\mathrm{g}}=5.78$ at $\alpha=95^{\circ}$ and $5.34 \mathrm{eV}$ at $\left.115^{\circ}\right)$. The $\mathrm{p}$ character of the $\mathrm{P}$ lone pair (HOMO) and, thus, its energy level, increases with larger angles $\alpha$, resulting in decreasing pyramidalization, while the LUMO is much less affected. The same trend is observed for $(Z)$ - and $(E)-\mathbf{3}$, both of which have been characterized crystallographically. The phosphorus atom in $(Z)-\mathbf{3}$ is less pyramidal than that of the $E$ isomer (the sum of the C-P-C angles: 273.9 vs. $259.9^{\circ}$, respectively), and, accordingly, is $48.4 \mathrm{ppm}$ less shielded $(Z: \quad \delta=-36.7 \mathrm{ppm}, \quad E: \quad \delta=$ $-85.1 \mathrm{ppm}){ }^{[8]}$

In complexes $\mathbf{4}$, the metal fragment, which is both a $\sigma$ acceptor and a $\pi$ donor, lowers the energy of the $\mathrm{P}$ lone pair and raises that of the empty phosphorus p orbital. ${ }^{[5 a]}$ However, a more negative paramagnetic contribution is observed for $4 \mathbf{b}$ than for uncomplexed $\mathbf{4} \mathbf{b}^{\prime}\left((Z)-\mathbf{4} \mathbf{b}: \sigma_{\text {Para }}=\right.$ $-635.4 \mathrm{ppm},(Z)-\mathbf{4} \mathbf{b}^{\prime}: \sigma_{\text {Para }}=-591.2 \mathrm{ppm}$; see Table 2) which is due to extra deshielding contributions of the complex that arise from the coupling between the occupied $\pi\left(\mathrm{PR}_{3}\right)$ and virtual $\sigma^{*}(\mathrm{PW})$ orbitals. ${ }^{[5 a]}$ As these transitions complicate 

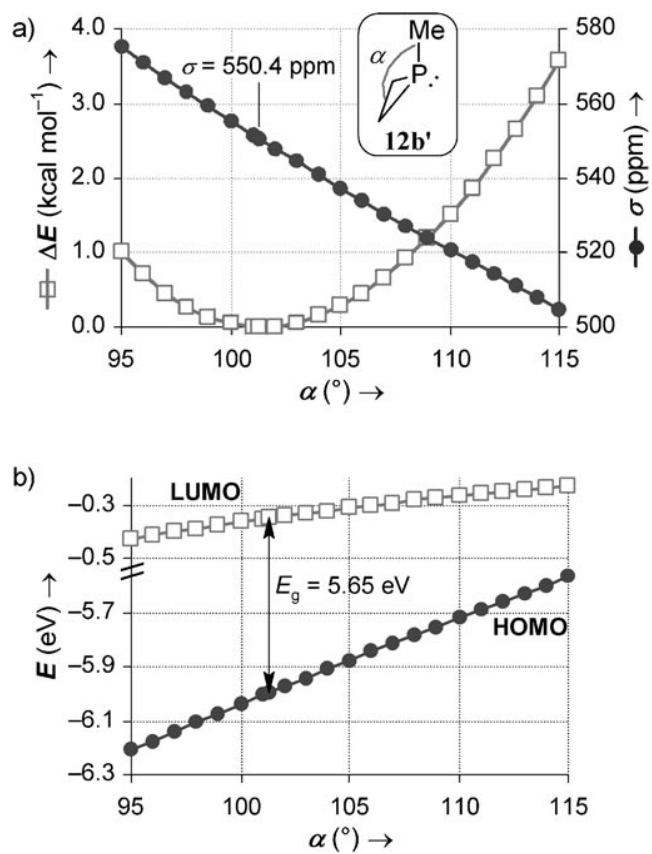

Figure 3. Effect of the phosphirane-Me angle $\alpha$ in $\mathbf{1 2} \mathbf{b}^{\prime}$ on a) the relative energy and the chemical shielding, and b) the HOMO and LUMO equilibrium gap energy $E_{\mathrm{g}}$.

more detailed analyses, we focused on the uncomplexed model systems $\mathbf{4} \mathbf{b}^{\prime}, \mathbf{1 3}$, and $\mathbf{1 4}$ (Table 2). The paramagnetic contribution $\sigma_{\text {Para }}$ is much larger for the $E$ than for the $Z$ isomer of each model compound except for 14; the differences in $\sigma_{\text {Dia }}$ are small. As the lone pair is more localized on $\mathrm{P}$ in $\mathbf{4} \mathbf{b}^{\prime}$ than in the complex $\mathbf{4 b}$, the phosphorus nucleus is more sensitive to the differences in the electronic structure of the isomers, which is expressed in an increase in $\Delta \sigma$ from 55 to $64 \mathrm{ppm}$.

To evaluate the influence of steric congestion on the Ppyramidalization, we replaced the bridgehead methyl groups in $\mathbf{4} \mathbf{b}^{\prime}$ with hydrogen atoms $(\mathbf{1 3})$. The result is that the $Z$ isomer becomes more pyramidal, as indicated by the angle $\alpha$ of $110.2^{\circ}$ for $(Z)-\mathbf{1 3}$ versus $114.5^{\circ}$ for (Z)-4 $\mathbf{b}^{\prime}$. Consequently, the HOMO is lowered with a concomitant increase in $E_{\mathrm{g}}$ from 4.33 to $4.44 \mathrm{eV}$. This effect is paralleled by a strong reduction of the paramagnetic deshielding from -591.2 for $(Z)-\mathbf{4} \mathbf{b}^{\prime}$ to $-551.8 \mathrm{ppm}$ for $(Z)-\mathbf{1 3}$. In contrast, the $E$ isomers show little structural change, and, hence, the $\sigma_{\text {Para }}$ contribution remains almost constant. Consequently, the difference in the total shielding $\sigma$ of the isomers is reduced from 64 for $(Z / E)-\mathbf{4} \mathbf{b}^{\prime}$ to $26 \mathrm{ppm}$ for $(Z / E)-\mathbf{1 3}$ (Table 2).

The effect of the cyclobutene moiety becomes apparent when we compare model systems $\mathbf{1 3}$ and $\mathbf{1 4}$, in which the unsaturated ring has been eliminated. The P-pyramidalization in the isomers of $\mathbf{1 3}$ and $\mathbf{1 4}$ is virtually unaffected (e.g., (Z)-13: $\left.\alpha=110.2^{\circ},(Z)-14: 110.0^{\circ}\right)$, yet the influence on the chemical shift difference between the $E$ and $Z$ isomers is large. While this difference is substantial for $\mathbf{1 3}(\Delta \sigma=$ $26.3 \mathrm{ppm})$, it vanished for $\mathbf{1 4}(\Delta \sigma=-1.9 \mathrm{ppm})$. For $(Z)-\mathbf{1 4}$, the $E_{\mathrm{g}}$ is even larger than for its $E$ isomer (5.30 vs. $5.02 \mathrm{eV}$, respectively), and the $\sigma_{\text {Para }}$ differs accordingly ( -513.5 vs. $-526.1 \mathrm{ppm})$, which thereby effectively counteracts the change in $\sigma_{\text {Dia }}$. The influence of the double bond becomes evident from the MO correlation diagrams for $\mathbf{1 3}$ and 14 that are shown in Figure 4. Compared to $\mathbf{1 4}$, the $\pi$ and $\pi^{*}$ components of the double bond in $\mathbf{1 3}$ participate in the HOMO and LUMO, respectively, causing a decrease in the energy difference $E_{\mathrm{g}}$. Due to its relative orientation, the HOMO of the $Z$ isomer is more destabilized (14: $E_{\mathrm{HOMO}}=$ $-5.50,13:-5.11 \mathrm{eV})$ than that of the $E$ isomer (14: $\left.E_{\mathrm{HOMO}}=-5.27, \quad 13:-5.22 \mathrm{eV}\right)$, resulting in a smaller HOMO-LUMO gap and, hence, a more negative $\sigma_{\text {Para }}((Z)$ 13: $-551.8, E$ : $-534.0 \mathrm{ppm})$.

The fused phosphiranes $\mathbf{1 4}$ are much less shielded than the parent phosphirane 12 $\mathbf{b}^{\prime}$ (compared to $(Z)-\mathbf{1 4}: \sigma=467.8$, $\mathbf{1 2} \mathbf{b}^{\prime}$ : $550.4 \mathrm{ppm}$, see Figure 3) as a result of their higher

Table 2. ${ }^{31} \mathrm{P}$ chemical shielding decompositions [ppm], phosphirane-Me angles $\alpha\left[{ }^{\circ}\right]$, and MO and gap energies [eV]; $Z$ isomers drawn.

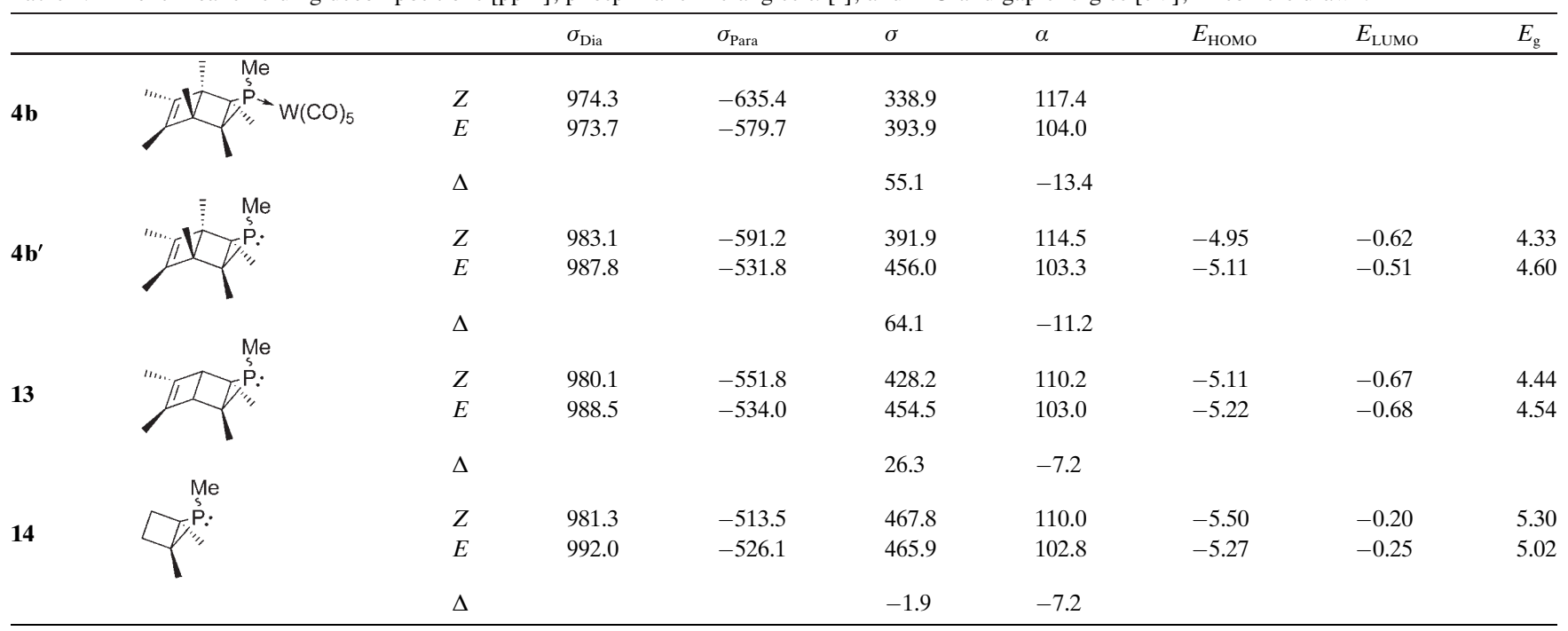



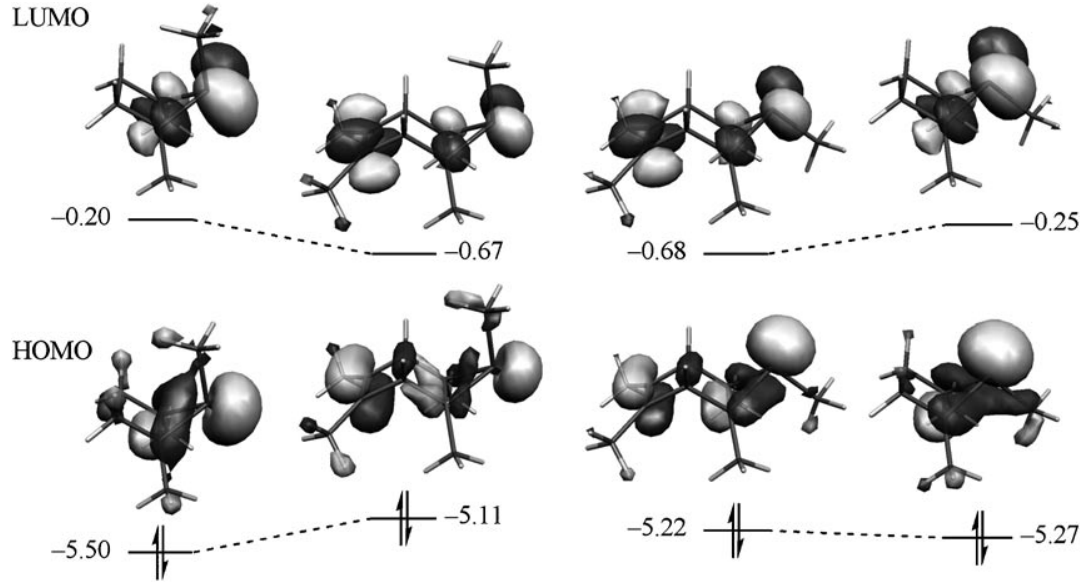

$E_{\mathrm{g}} 5.30(Z)-14$

(Z)-13 4.44
(E)-14 5.02

Figure 4. Correlation diagram for $(Z / E)-\mathbf{1 4}$ and 13, including MO energies and gap energies $E_{\mathrm{g}}(\mathrm{eV})$.

similar interactions with the $\mathrm{W}(\mathrm{CO})_{5}$ group in the $E$ isomer. In fact, $(E)-\mathbf{4 b}$ is favored over the $Z$ isomer by only $0.5 \mathrm{kcal} \mathrm{mol}^{-1}$ at the BP86/TZP level.

Steric congestion of the substrate: Substrates with two double bonds can give both single and double phosphinidene addition, ${ }^{[9 c, 29]}$ but only the mono-adducts were obtained in the case of hexamethyl Dewar benzene (HMDB) (9). We ascribe this to the steric congestion of the double bonds. When
HOMO energies $((Z)-\mathbf{1 4}:-5.50$ vs. $12 \mathbf{b}^{\prime}$ : $\left.-5.99 \mathrm{eV}\right)$, which leads to smaller energy gaps and, consequently, to stronger paramagnetic deshieldings.

In summary, the low-field ${ }^{31} \mathrm{P}$ chemical shift of (Z)-4 as compared to the $E$ isomer is caused by 1 ) the reduced P-pyramidalization of the $Z$ isomer due to steric interactions with the central bridge methyl groups and 2) the stronger interaction of the double bond with the phosphorus lone pair in the $Z$ isomer.

Ring strain: For comparison of the ring strain in $\mathbf{4}$ and $\mathbf{9}$, we used the uncomplexed annellated methylphosphirane $\mathbf{4} \mathbf{b}^{\prime}$ as a model compound. The reaction enthalpies of homodesmotic reactions ${ }^{[24]}$ given in Equations (1)-(3) were calculated at the G3(MP2)//B3 LYP/6-31G(d) level of theory. ${ }^{[25,26]}$ The calculated strain energy of $42.7 \mathrm{kcal} \mathrm{mol}^{-1}$ for 9 is in excellent agreement with previous experimental estimates of 40 $45 \mathrm{kcal} \mathrm{mol}^{-1}{ }^{[27]}$ while the annellated phosphirane $(E)-\mathbf{4} \mathbf{b}^{\prime}$ has a larger ring-strain energy of $53.9 \mathrm{kcal} \mathrm{mol}^{-1}$. The phosphirane ring apparently introduces $11.2 \mathrm{kcal} \mathrm{mol}^{-1}$ extra ring strain, which is, however, half of that calculated for the parent phosphirane $\mathrm{C}_{2} \mathrm{H}_{4} \mathrm{PH} \cdot{ }^{[24 \mathrm{~b}]}$ The modest contribution of the CCP ring to the strain energy of $\mathbf{4} \mathbf{b}^{\prime}$ is partly due to the release of $4.7 \mathrm{kcal} \mathrm{mol}^{-1}$ of olefin strain in $\mathbf{4} \mathbf{b}^{\prime}$ [reactions (1) vs. (3)], ${ }^{[28]}$ which compares well with the $5.3 \mathrm{kcal} \mathrm{mol}^{-1}$ of olefin strain reported for cyclobutene. ${ }^{[24 b, 9 b]}$

At this level of theory, $(Z)-\mathbf{4} \mathbf{b}^{\prime}$ is $4.7 \mathrm{kcal} \mathrm{mol}^{-1}$ less stable than the $(E)-\mathbf{4} \mathbf{b}^{\prime}$ isomer due to the steric interactions between the $\mathrm{P}-\mathrm{Me}$ group and the bridgehead methyl groups. For complexed 4, this energy difference is largely offset by we used, instead of $\mathbf{1 0}$, the "classical" phosphinidene precursor 16 with $10 \% \mathrm{CuCl}$ as a catalyst, ${ }^{[30]}$ only $23 \%$ conversion to $4 \mathbf{a}(Z / E$ 5:1) was observed under similar reaction conditions. Several byproducts were formed, most notably diphosphene $(15 \%)$ and triphosphirane $(6 \%)$, which are known decomposition products of $\mathbf{1 6}$ in the absence of a substrate. ${ }^{[31]}$

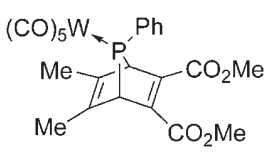

16
Reaction at room temperature with a fivefold excess of 9 and $5 \% \mathrm{CuCl}$ did not improve the conversion. These observations are consistent with the proposed intermediacy of a phosphinidene- $\mathrm{CuCl}$ species, ${ }^{[32,8,9 b, c]}$ which is sterically more demanding than the "free" phosphinidene complex generated without the $\mathrm{Cu}^{\mathrm{I}}$ catalyst. Thermal decomposition of $\mathbf{1 6}$ at $110^{\circ} \mathrm{C}$ with a fivefold excess of $\mathbf{9}$ afforded a cleaner reaction, ${ }^{[33]}$, but still only $31 \%$ conversion to $(Z)-\mathbf{4 a}$ was obtained. The small amount of $E$ isomer that was also ob- 
served during the course of the reaction was not stable at the reaction temperature. These results signify the steric congestion in the substrate 9 and the suitability of benzophosphepine $\mathbf{1 0}$ as a low-temperature precursor of transient phosphinidene complexes.

Second cycloaddition: Products $4 \mathbf{a}$ and $\mathbf{4 b}$ still contained a (hindered) double bond, and we attempted to expand the annellated system with a subsequent cycloaddition (Scheme 2). Reaction of $\mathbf{4 a}$ or $\mathbf{4 b}$ with the corresponding rated by $2 \mathrm{D}$ NOESY measurements. The correlation of the central bridgehead methyl groups (at $\mathrm{C} 3 / 6$ ) with those at $\mathrm{C} 4 / 5$ (epoxide) is weaker than for the starting material $(Z)$ 4a. This is consistent with their increased distance in 18, whereas in endo-epoxide $\mathbf{1 9}$ these methyl groups would be closer to each other than in (Z)-4a. Moreover, an interaction is observed between the methyl groups of the phosphirane ring and those of the epoxide ring, which would be absent in 19. Finally, we calculated ${ }^{31} \mathrm{P}$ NMR chemical shifts at the BP86/TZP level ${ }^{[22]}$ for epoxides 18 and $\mathbf{1 9}$ of $\delta_{\text {calcd }}=$ -68.7 and $-88.8 \mathrm{ppm} \quad\left(\sigma_{\text {calcd }}=\right.$ $325.9,345.9 \mathrm{ppm})$, respectively. The chemical shift for $\mathbf{1 8}$ is in excellent agreement with the experimentally observed ${ }^{31} \mathrm{P}$ NMR chemical shift of $\delta=$ $-69.9 \mathrm{ppm}$.

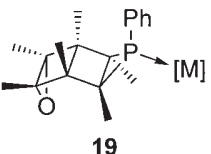

\section{Conclusion}

Tricyclic exo-phosphiranes 4 have been synthesized by phos-

benzophosphepine $\mathbf{1 0}\left(\mathbf{a}: 65^{\circ} \mathrm{C}, \mathbf{b}: 75^{\circ} \mathrm{C}\right)$ only resulted in decomposition of the precursor. ${ }^{[14 b]}$ Clearly, the double bond in 4 is not accessible for phosphinidene addition. The crystal structure of $4 \mathbf{a}$ shows that the central methyl groups (C9 and $\mathrm{C} 12$ ) are tilted toward the double bond, which is in accordance with the observed reduced accessibility.

We reasoned that addition of the smaller singlet methylene $\mathrm{H}_{2} \mathrm{C}$ : might possibly afford the cyclopropane derivative 17. The use of the Simmons-Smith carbenoid $\left[\mathrm{IZnCH}_{2} \mathrm{I}\right]$, conveniently generated from diiodomethane and diethylzinc in hexane, ${ }^{[34]}$ was an evident choice. However, whereas 9 was fully converted by excess carbenoid to a mixture of mono- and bis-adduct (5a and $\mathbf{6 a}$, Scheme 3), no addition

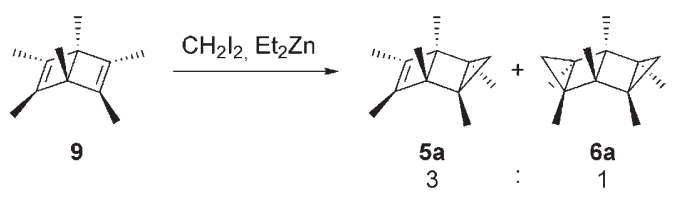

Scheme 3 . Methylene addition to 9 with product ratio.

was observed for $(Z)-4 a$. Instead, epoxidation with $m$-chloroperbenzoic acid (MCPBA), analogous to the generation of $\mathbf{5} \mathbf{b}$ and $\mathbf{6} \mathbf{b}^{[11]}$ was more successful. Thus, reaction of $(Z)$ $4 \mathbf{a}$ with a threefold excess of MCPBA resulted in $42 \%$ (by NMR spectroscopy) of tetracyclic $18\left(\delta_{\mathrm{P}}=-69.9 \mathrm{ppm}\right)$. $^{[35]}$ The presence of an epoxide ring in complex $\mathbf{1 8}$ was established by multinuclear NMR spectroscopy; the spectra indicate that $C_{\mathrm{s}}$ symmetry is retained. In this complex, the vinylic carbon resonance of $(Z)-\mathbf{4 a}(146.5 \mathrm{ppm})$ is replaced by one at $\delta=73.1 \mathrm{ppm}$, which is typical for epoxides (compared to $\left.\mathbf{5 b}: \delta=75.1 \mathrm{ppm}, \mathbf{6} \mathbf{b}: \delta=68.6 \mathrm{ppm}^{[11 \mathrm{c}]}\right)$. The presence of an exo-epoxide ring, analogous to $5 \mathbf{b}$ and $\mathbf{6 b}$ was corrobo- phinidene addition to $\mathbf{9}$. Benzophosphepine $\mathbf{1 0}$ is a suitable phosphinidene precursor for such sterically hindered substrates. The remaining double bond is unreactive toward further 1,2-addition by phosphinidene or methylene species, but can be epoxidized with MCPBA to a tetracyclic P,O-bisadduct. The large difference in ${ }^{31} \mathrm{P}$ NMR chemical shift of congestion around the phosphorus atom and electronic interaction of the (coordinated) phosphorus lone pair with the double bond in the $Z$ isomer, both of which cause deshielding relative to the $E$ isomer. The semiquantitative results of our calculations provide a more systematic understanding of structural influences on ${ }^{31} \mathrm{P}$ chemical shieldings. This may pave the way to using ${ }^{31} \mathrm{P}$ NMR spectroscopy to monitor structural differences of tailored phosphine ligands in catalysis.

\section{Experimental Section}

Computation of ${ }^{31} \mathbf{P}$ NMR chemical shieldings: Hybrid density-functional theory geometry optimizations were carried out with ADF 2004.01 at the Becke 88-Perdew 86/TZP level, ${ }^{[22]}$ by using an integration accuracy of 6.0 and convergence criteria of $1 \times 10^{-6}$ for the SCF and $1 \times 10^{-4}$ for the geometry. Subsequently, a single-point SCF calculation was performed with the PBE functional, using a basis set of TZP ( $4 \mathrm{~d}$ frozen) for W and ETpVQZ for all other elements. The resulting wave function and potential were supplied to ADF's EPR/NMR program to calculate the ${ }^{31} \mathrm{P}$ chemical shielding. These values are relative to a bare phosphorus nucleus and can be converted to chemical shifts $\delta$ relative to an appropriate reference system, for which we used the phosphirane complex $\mathbf{1 2 b}\left(\sigma_{\text {calcd }}=456.4\right.$, $\left.\delta_{\text {exptl }}=-199.3 \mathrm{ppm}\right)$ to obtain the relationship: $\delta_{\text {calcd }}($ adduct $)=$ $257.1 \mathrm{ppm}-\sigma_{\text {calcd }}($ adduct $)$. Reported shielding contributions are rounded to one, and BP86/TZP MO energies to two decimal places.

Ring strain analyses: Structures were optimized with Gaussian 03 $(\mathrm{G} 03)^{[25]}$ at the B3LYP/6-31G(d) level of theory by using tight SCF and $(Z)$ - and $(E)-\mathbf{4}$ is found to be due to a combination of steric 
geometry convergence criteria and an ultrafine integration grid and were verified as minima by frequency calculations. The strain energies were determined by calculating the G3(MP2)//B3 LYP/6-31G(d) enthalpies at $298.15 \mathrm{~K}$ for the homodesmotic reactions. The size of $(Z / E)-\mathbf{4} \mathbf{b}^{\prime}$ required the use of a 64 bits implementation of G03.

General: All reactions were carried out under nitrogen using standard Schlenk techniques. Hexamethyl Dewar benzene (9), dichloromethane (DCM), and $70 \% m$-chloroperbenzoic acid (MCPBA) were used as received. Diethylzinc was purchased as a $1.0 \mathrm{~m}$ solution in hexanes. Toluene was distilled over sodium. The syntheses of benzophosphepines $10 \mathbf{a}$ and $10 \mathrm{~b}$ have been described elsewhere. ${ }^{[14]}$ NMR measurements were performed (at $298 \mathrm{~K}$ ) on a Bruker Avance $250\left({ }^{1} \mathrm{H},{ }^{13} \mathrm{C},{ }^{31} \mathrm{P}\right)$ or a Bruker Avance $400\left({ }^{1} \mathrm{H},{ }^{13} \mathrm{C}, 2 \mathrm{D}\right.$ spectra $)$. NMR chemical shifts were internally referenced to the solvent for ${ }^{1} \mathrm{H}\left(\mathrm{CHCl}_{3}: \delta=7.26 \mathrm{ppm}, \mathrm{C}_{6} \mathrm{HD}_{5}: \delta=\right.$ $7.16 \mathrm{ppm})$ and ${ }^{13} \mathrm{C}\left(\mathrm{CDCl}_{3}: \delta=77.16 \mathrm{ppm}, \mathrm{C}_{6} \mathrm{D}_{6}: \delta=128.06 \mathrm{ppm}\right),{ }^{[36]}$ and externally for ${ }^{31} \mathrm{P}$ to $85 \% \mathrm{H}_{3} \mathrm{PO}_{4}$. Infrared (IR) spectra were recorded on a Mattson-6030 Galaxy Series FTIR spectrometer, and GC-MS spectra on a HP 5890 Series II GC (column BP5 $25 \mathrm{~m}, 0.25 \mathrm{~mm}$ ID) with a HP 5971 Series MS unit. High-resolution mass spectra (HR-MS) were measured on a Finnigan Mat 900 mass spectrometer operating at an ionization potential of $70 \mathrm{eV}$. The elemental analysis of $(Z)-\mathbf{4 a}$ was performed by the Microanalytical Laboratory of the Laboratorium für Organische Chemie, ETH Zürich. Melting points were measured on samples in unsealed capillaries and are uncorrected.

\section{(Hexamethyl-3-phenyl-3-phosphatricyclo[3.2.0.0 $\left.{ }^{2,4}\right]$ hept-6-en-3-yl)penta-} carbonyltungsten (4a)

Procedure A: 10a $(125.95 \mathrm{mg}, 225 \mu \mathrm{mol})$ and $9(90.9 \mu \mathrm{L}, 450 \mu \mathrm{mol})$ were dissolved in toluene $(2.25 \mathrm{~mL})$, and heated to $55^{\circ} \mathrm{C}$ for 4.5 days. ${ }^{31} \mathrm{P}$ NMR spectroscopy showed complete conversion to $\mathbf{4 a}(Z / E$ 1.1:1). Volatiles were evaporated and the crude product was purified by column chromatography over silica gel eluted with pentane, which yielded a white solid ( $80.8 \mathrm{mg}, 136 \mu \mathrm{mol}, 60 \%$ ). The $Z$ isomer could be separated from the $E$ by column chromatography over silica gel eluted with 19:1 pentane/ DCM, followed by fractional crystallization from hexane at $-20^{\circ} \mathrm{C}$.

(Z)-4a: Colorless crystalline solid, m.p. $=145^{\circ} \mathrm{C}$ (decomp); $R_{\mathrm{f}}$ (silica/pentane): $0.30 ;{ }^{1} \mathrm{H} \mathrm{NMR}\left(250.1 \mathrm{MHz}, \mathrm{CDCl}_{3}\right): \delta=7.54\left(\mathrm{ddd},{ }^{3} J_{\mathrm{HP}}=10.8\right.$, $\left.{ }^{3} J_{\mathrm{HH}}=7.8,{ }^{4} J_{\mathrm{HH}}=1.6 \mathrm{~Hz}, 2 \mathrm{H} ; o-\mathrm{PhH}\right), 7.38-7.26(\mathrm{~m}, 3 \mathrm{H} ; \mathrm{m} / p-\mathrm{PhH}), 1.68$ $\left(\mathrm{d},{ }^{5} J_{\mathrm{HP}}=0.9 \mathrm{~Hz}, 6 \mathrm{H} ;=\mathrm{CMe}\right), 1.51\left(\mathrm{~d},{ }^{3} J_{\mathrm{HP}}=16.4 \mathrm{~Hz}, 6 \mathrm{H} ; \mathrm{PCMe}\right)$, $0.84 \mathrm{ppm}$ (s, 6H; PCCMe); $\left.{ }^{13} \mathrm{C}^{1}{ }^{1} \mathrm{H}\right\}$ NMR $\left(100.6 \mathrm{MHz}, \mathrm{CDCl}_{3}\right): \delta=199.7$ $\left(\mathrm{d},{ }^{2} J_{\mathrm{CP}}=27.2 \mathrm{~Hz}, \mathrm{CO}_{\mathrm{ax}}\right), 196.7\left(\mathrm{~d},{ }^{2} J_{\mathrm{CP}}=7.9 \mathrm{~Hz}, \mathrm{CO}_{\mathrm{eq}}\right), 146.5\left(\mathrm{~d},{ }^{3} J_{\mathrm{CP}}=\right.$ $4.6 \mathrm{~Hz},=\mathrm{C}), 137.6\left(\mathrm{~d},{ }^{1} J_{\mathrm{CP}}=17.2 \mathrm{~Hz}\right.$, ipso-Ph $), 133.1\left(\mathrm{~d},{ }^{2} J_{\mathrm{CP}}=11.3 \mathrm{~Hz}, o\right.$ $\mathrm{Ph}), 129.6\left(\mathrm{~d},{ }^{4} J_{\mathrm{CP}}=2.0 \mathrm{~Hz}, p-\mathrm{Ph}\right), 127.9\left(\mathrm{~d},{ }^{3} J_{\mathrm{CP}}=9.4 \mathrm{~Hz}, m-\mathrm{Ph}\right), 54.3(\mathrm{~d}$, $\left.{ }^{2} J_{\mathrm{CP}}=7.8 \mathrm{~Hz}, \mathrm{PCC}\right), 49.3\left(\mathrm{~d},{ }^{1} J_{\mathrm{CP}}=18.0 \mathrm{~Hz}, \mathrm{PC}\right), 15.5\left(\mathrm{~d},{ }^{2} J_{\mathrm{CP}}=10.3 \mathrm{~Hz}\right.$, $\mathrm{PCMe}), 11.4\left(\mathrm{~d},{ }^{3} J_{\mathrm{CP}}=2.9 \mathrm{~Hz}, \mathrm{PCCMe}\right), 11.0 \mathrm{ppm}(\mathrm{s},=\mathrm{CMe}) ;{ }^{31} \mathrm{P}\left\{{ }^{1} \mathrm{H}\right\}$ NMR (101.3 MHz, $\left.\mathrm{CDCl}_{3}\right): \delta=-63.0 \mathrm{ppm}\left({ }^{1} J_{\mathrm{PW}}=250.3 \mathrm{~Hz}\right)$; IR $(\mathrm{KBr})$ : $\bar{v}=2069.5\left(\mathrm{~m}, \mathrm{CO}_{\mathrm{ax}}\right), 1928.5,1910.8 \mathrm{~cm}^{-1}\left(\mathrm{br} \mathrm{s}, \mathrm{CO}_{\mathrm{eq}}\right)$; HR-MS: calcd for $\mathrm{C}_{23} \mathrm{H}_{23} \mathrm{O}_{5} \mathrm{PW}$ : 594.0793; found: 594.0795; $\mathrm{m} / z$ (\%): 594 (2) $[M]^{+}, 510$ (1) $[M-3 \mathrm{CO}]^{+}, 482(1)[M-4 \mathrm{CO}]^{+}, 454(36)[M-5 \mathrm{CO}]^{+}, 452(41), 432(14)$ $[M-9]^{+}, 404(100)[M-9-\mathrm{CO}]^{+}, 376(18)[M-9-2 \mathrm{CO}]^{+}, 348(92)$ $[M-9-3 \mathrm{CO}]^{+}, 320(31)[M-9-4 \mathrm{CO}]^{+}, 292(31)[M-9-5 \mathrm{CO}]^{+}, 161$ (15) [hexamethyl benzene (HMB)-H $]^{+}, 147(37)[\mathrm{HMB}-\mathrm{Me}]^{+}$; elemental analysis calcd (\%) for $\mathrm{C}_{23} \mathrm{H}_{23} \mathrm{O}_{5} \mathrm{PW}$ : $\mathrm{C} 46.49, \mathrm{H} 3.90$; found: $\mathrm{C} 46.62$, $\mathrm{H}$ 3.97. (E)-4a: $R_{\mathrm{f}}$ (silica/pentane): $0.25 ;{ }^{1} \mathrm{H} \mathrm{NMR}\left(400.1 \mathrm{MHz}, \mathrm{CDCl}_{3}\right.$ ): $\delta=7.37\left(\mathrm{td},{ }^{3} J_{\mathrm{HH}}=7.4,{ }^{4} J_{\mathrm{HP}}=2.5 \mathrm{~Hz}, 2 \mathrm{H} ; m-\mathrm{PhH}\right), 7.31-7.25(\mathrm{~m}, 3 \mathrm{H} ; o / p-$ $\mathrm{PhH}), 1.68\left(\mathrm{~d},{ }^{5} J_{\mathrm{HP}}=1.2 \mathrm{~Hz}, 6 \mathrm{H}\right.$; $\left.=\mathrm{CMe}\right), 1.29$ (s, 6H; PCCMe), $1.27 \mathrm{ppm}$ $\left(\mathrm{d},{ }^{3} J_{\mathrm{HP}}=10.2 \mathrm{~Hz}, 6 \mathrm{H} ; \mathrm{PCMe}\right) ;{ }^{13} \mathrm{C}\left\{{ }^{1} \mathrm{H}\right\}$ NMR $\left(100.6 \mathrm{MHz}, \mathrm{CDCl}_{3}\right): \delta=$ $199.2\left(\mathrm{~d},{ }^{2} J_{\mathrm{CP}}=30.5 \mathrm{~Hz}, \mathrm{CO}_{\mathrm{ax}}\right), 197.5\left(\mathrm{~d},{ }^{2} J_{\mathrm{CP}}=7.6 \mathrm{~Hz}, \mathrm{CO}_{\mathrm{eq}}\right), 143.2(\mathrm{~d}$, $\left.{ }^{3} J_{\mathrm{CP}}=6.7 \mathrm{~Hz},=\mathrm{C}\right), 139.6\left(\mathrm{~d},{ }^{1} J_{\mathrm{CP}}=28.0 \mathrm{~Hz}\right.$, ipso- $\left.\mathrm{Ph}\right), 132.8\left(\mathrm{~d},{ }^{2} J_{\mathrm{CP}}=\right.$ $9.2 \mathrm{~Hz}, o-\mathrm{Ph}), 129.1\left(\mathrm{~d},{ }^{4} J_{\mathrm{CP}}=1.1 \mathrm{~Hz}, p-\mathrm{Ph}\right), 128.9\left(\mathrm{~d},{ }^{3} J_{\mathrm{CP}}=8.3 \mathrm{~Hz}, m-\mathrm{Ph}\right)$, $55.1\left(\mathrm{~d},{ }^{2} J_{\mathrm{CP}}=4.7 \mathrm{~Hz}, \mathrm{PCC}\right), 44.9\left(\mathrm{~d},{ }^{1} J_{\mathrm{CP}}=15.5 \mathrm{~Hz}, \mathrm{PC}\right), 13.3(\mathrm{~s}, \mathrm{PCCMe})$, $12.2\left(\mathrm{~d}, \quad{ }^{3} J_{\mathrm{CP}}=7.2 \mathrm{~Hz}, \quad \mathrm{PCMe}\right), \quad 10.8 \mathrm{ppm} \quad(\mathrm{s},=\mathrm{CMe}) ;{ }^{31} \mathrm{P}\left\{{ }^{1} \mathrm{H}\right\} \quad \mathrm{NMR}$ $\left(101.3 \mathrm{MHz}, \mathrm{CDCl}_{3}\right): \delta=-126.9 \mathrm{ppm}\left({ }^{1} J_{\mathrm{PW}}=241.5 \mathrm{~Hz}\right)$.

Procedure B: $\mathrm{CuCl}(1.2 \mathrm{mg}, 12 \mu \mathrm{mol}, 10 \%)$, complex 16a $(81.4 \mathrm{mg}$, $137 \mu \mathrm{mol})$, and $9(24.5 \mu \mathrm{L}, 121 \mu \mathrm{mol})$ were heated in toluene $(0.4 \mathrm{~mL})$ at $50{ }^{\circ} \mathrm{C}$ for $4.5 \mathrm{~h} .{ }^{31} \mathrm{P}$ NMR spectroscopy of the resulting intense red mixture indicated $23 \%$ conversion to 4 a $(Z / E 5: 1)$, along with diphosphene $\left(15 \%, \delta_{\mathrm{P}}=-18 \mathrm{ppm}\left({ }^{1} J_{\mathrm{PW}}=139,{ }^{1} J_{\mathrm{PW}}=103,{ }^{2} J_{\mathrm{PW}}=32 \mathrm{~Hz}\right)\right)$, triphosphirane $\left(6 \%, \delta_{\mathrm{P}}=-92\left(\mathrm{dd},{ }^{1} J_{\mathrm{PP}}=215,{ }^{1} J_{\mathrm{PP}}=176 \mathrm{~Hz}\right),-119\left(\mathrm{dd},{ }^{1} J_{\mathrm{PP}}=176\right.\right.$, $\left.\left.{ }^{1} J_{\mathrm{PP}}=165 \mathrm{~Hz}\right), \quad-129 \mathrm{ppm} \quad\left(\mathrm{dd},{ }^{1} J_{\mathrm{PP}}=215,{ }^{1} J_{\mathrm{PP}}=165 \mathrm{~Hz}\right)\right)$, and small amounts of other unidentified byproducts.

Procedure $C$ : $\mathrm{CuCl}(0.6 \mathrm{mg}, 6 \mu \mathrm{mol}, 5 \%)$, complex 16a $(79.5 \mathrm{mg}$, $122 \mu \mathrm{mol})$, and $9(125 \mu \mathrm{L}, 619 \mu \mathrm{mol})$ were stirred in toluene $(1.5 \mathrm{~mL})$ at room temperature for 10 days. ${ }^{31} \mathrm{P}$ NMR spectroscopy of the resulting intense red mixture indicated $24 \%$ conversion to $\mathbf{4 a}(Z / E$ 8:1).

Procedure D: Complex 16a $(37.3 \mathrm{mg}, 57 \mu \mathrm{mol})$ and $9(58 \mu \mathrm{L}, 287 \mu \mathrm{mol})$ were dissolved in toluene $(0.50 \mathrm{~mL})$, and heated to $110^{\circ} \mathrm{C}$ for $20 \mathrm{~h}$. Conversion to 4a was determined by ${ }^{31} \mathrm{P}$ NMR spectroscopy: $26 \%$ after $4 \mathrm{~h}$ $(Z / E 7: 1), 31 \%$ after $20 \mathrm{~h}$ (only $Z$ )

(Heptamethyl-3-phosphatricyclo[3.2.0.0 $\left.{ }^{2,4}\right]$ hept-6-en-3-yl)pentacarbonyltungsten (4b): Compound $10 \mathrm{~b}(299 \mathrm{mg}, 0.60 \mathrm{mmol})$ and $9(303 \mu \mathrm{L}$ $1.50 \mathrm{mmol})$ were dissolved in toluene $(5.0 \mathrm{~mL})$ and heated to $65^{\circ} \mathrm{C}$ for 6 days. ${ }^{31} \mathrm{P}$ NMR spectroscopy showed complete conversion to $\mathbf{4 b}(Z / E$ 1.4:1) with traces of byproduct at $\delta=-21.0$ and $-125.7(\mathrm{~d}, J=13.7 \mathrm{~Hz})$, -23.4 and $-150.7 \mathrm{ppm}(\mathrm{d}, J=14.4 \mathrm{~Hz}$ ), which we ascribed to decomposition products of $\mathbf{1 0 b}$ in analogy with $\mathbf{1 0} \mathbf{a}^{[14 \mathrm{~b}]}$ Volatiles were evaporated and the crude product was purified by column chromatography over silica gel eluted with 19:1 pentane/toluene. The obtained off-white solid $(0.211 \mathrm{~g}, 0.40 \mathrm{mmol}, 66 \%)$ also contained $8 \%$ hexamethyl benzene, but we were unable to remove this impurity by column chromatography and crystallization. $Z$ and $E$ enriched fractions were obtained by preparative thin-layer chromatography eluted with $1 \%$ diethyl ether (DEE) in pentane. (Z)-4b: $R_{\mathrm{f}}$ (silica/pentane): $0.40 ;{ }^{1} \mathrm{H} \mathrm{NMR}\left(400.1 \mathrm{MHz}, \mathrm{C}_{6} \mathrm{D}_{6}\right): \delta=$ $1.37\left(\mathrm{~d},{ }^{5} J_{\mathrm{HP}}=0.9 \mathrm{~Hz}, 6 \mathrm{H} ;=\mathrm{CMe}\right), 1.35\left(\mathrm{~d},{ }^{2} J_{\mathrm{HP}}=7.0 \mathrm{~Hz}, 3 \mathrm{H} ; \mathrm{PMe}\right), 1.17$ $\left(\mathrm{d},{ }^{3} J_{\mathrm{HP}}=15.8 \mathrm{~Hz}, 6 \mathrm{H}\right.$; PCMe $), 0.75 \mathrm{ppm}(\mathrm{s}, 6 \mathrm{H} ; \mathrm{PCCMe}) ;{ }^{13} \mathrm{C}\left\{{ }^{1} \mathrm{H}\right\}$ NMR $\left(100.6 \mathrm{MHz}, \mathrm{C}_{6} \mathrm{D}_{6}\right): \delta=198.7\left(\mathrm{~d},{ }^{2} J_{\mathrm{CP}}=26.2 \mathrm{~Hz}, \mathrm{CO}_{\mathrm{ax}}\right), 197.0\left(\mathrm{~d},{ }^{2} J_{\mathrm{CP}}=\right.$ $\left.8.0 \mathrm{~Hz}, \mathrm{CO}_{\mathrm{eq}}\right), 144.2\left(\mathrm{~d},{ }^{3} J_{\mathrm{CP}}=4.7 \mathrm{~Hz},=\mathrm{C}\right), 55.9\left(\mathrm{~d},{ }^{2} J_{\mathrm{CP}}=6.9 \mathrm{~Hz}, \mathrm{PCC}\right)$, $45.7\left(\mathrm{~d},{ }^{1} J_{\mathrm{CP}}=14.1 \mathrm{~Hz}, \mathrm{PC}\right), 16.1\left(\mathrm{~d},{ }^{1} J_{\mathrm{CP}}=4.7 \mathrm{~Hz}, \mathrm{PMe}\right), 14.1\left(\mathrm{~d},{ }^{2} J_{\mathrm{CP}}=\right.$ $9.5 \mathrm{~Hz}, \mathrm{PCMe}), 12.8\left(\mathrm{~d},{ }^{3} J_{\mathrm{CP}}=3.0 \mathrm{~Hz}, \mathrm{PCCMe}\right), 10.4 \mathrm{ppm}(\mathrm{s},=\mathrm{CMe})$; ${ }^{31} \mathrm{P}\left\{{ }^{1} \mathrm{H}\right\} \operatorname{NMR}\left(101.3 \mathrm{MHz}, \mathrm{C}_{6} \mathrm{D}_{6}\right): \delta=-87.1 \mathrm{ppm}\left({ }^{1} J_{\mathrm{PW}}=249.2 \mathrm{~Hz}\right)$.

(E)-4b: $R_{\mathrm{f}}$ (silica/pentane): $0.35 ;{ }^{1} \mathrm{H}$ NMR $\left(400.1 \mathrm{MHz}, \mathrm{C}_{6} \mathrm{D}_{6}\right): \delta=1.40$ $\left(\mathrm{d},{ }^{5} J_{\mathrm{HP}}=1.3 \mathrm{~Hz}, 6 \mathrm{H}\right.$; $\left.=\mathrm{CMe}\right), 1.14(\mathrm{~s}, 6 \mathrm{H} ; \mathrm{PCCMe}), 0.89\left(\mathrm{~d},{ }^{3} J_{\mathrm{HP}}=\right.$ $9.9 \mathrm{~Hz}, 6 \mathrm{H}$; PCMe $), 0.86 \mathrm{ppm}\left(\mathrm{d},{ }^{2} J_{\mathrm{HP}}=5.4 \mathrm{~Hz}, 3 \mathrm{H}\right.$; PMe $) ;{ }^{13} \mathrm{C}\left\{{ }^{1} \mathrm{H}\right\} \mathrm{NMR}$ $\left(100.6 \mathrm{MHz}, \mathrm{C}_{6} \mathrm{D}_{6}\right): \delta=198.5\left(\mathrm{~d},{ }^{2} J_{\mathrm{CP}}=28.7 \mathrm{~Hz}, \mathrm{CO}_{\mathrm{ax}}\right), 198.0\left(\mathrm{~d},{ }^{2} J_{\mathrm{CP}}=\right.$ $\left.7.7 \mathrm{~Hz}, \mathrm{CO}_{\mathrm{eq}}\right), 143.3\left(\mathrm{~d},{ }^{3} J_{\mathrm{CP}}=6.7 \mathrm{~Hz},=\mathrm{C}\right), 54.1\left(\mathrm{~d},{ }^{2} J_{\mathrm{CP}}=4.0 \mathrm{~Hz}, \mathrm{PCC}\right)$, $43.1\left(\mathrm{~d},{ }^{1} J_{\mathrm{CP}}=11.1 \mathrm{~Hz}, \mathrm{PC}\right), 16.7\left(\mathrm{~d},{ }^{1} J_{\mathrm{CP}}=15.8 \mathrm{~Hz}, \mathrm{PMe}\right), 11.7\left(\mathrm{~d},{ }^{3} J_{\mathrm{CP}}=\right.$ $6.6 \mathrm{~Hz}, \mathrm{PCCMe}), 10.5(\mathrm{~s},=\mathrm{CMe}), 9.80 \mathrm{ppm}(\mathrm{s}, \mathrm{PCMe}) ;{ }^{31} \mathrm{P}\left\{{ }^{1} \mathrm{H}\right\}$ NMR $\left(101.3 \mathrm{MHz}, \mathrm{C}_{6} \mathrm{D}_{6}\right): \delta=-138.2\left({ }^{1} J_{\mathrm{PW}}=241.1 \mathrm{~Hz}\right)$; HR-MS: calcd for $\mathrm{C}_{18} \mathrm{H}_{21} \mathrm{O}_{5} \mathrm{PW}: 532.06359$; found: 532.06547; m/z (\%): 532 (4) $[M]^{+}, 504$ (2) $[M-\mathrm{CO}]^{+}, 476$ (1) $[M-2 \mathrm{CO}]^{+}, 448$ (2) $[M-3 \mathrm{CO}]^{+}, 433$ (5) $[M-\mathrm{Me}-3 \mathrm{CO}]^{+}, 390(8), 377(9)[M-\mathrm{Me}-6 \mathrm{CO}]^{+}, 370(11)[M-9]^{+}$, $342(41)[M-9-\mathrm{CO}]^{+}, 314(12)[M-9-2 \mathrm{CO}]^{+}, 286(7)[M-9-3 \mathrm{CO}]^{+}$, $258(4)[M-9-4 \mathrm{CO}]^{+}, 162(56)[\mathrm{HMB}]^{+}, 147.1(100)[\mathrm{HMB}-\mathrm{Me}]^{+}$.

(1-Methylphosphiran-1-yl)pentacarbonyltungsten $\quad(\mathbf{1 2 b}):^{[18]}$ Compound $16 \mathbf{b}(100 \mathrm{mg}, 0.17 \mathrm{mmol})$ in toluene $(2 \mathrm{~mL})$ was transferred to a $5 \mathrm{~mL}$ pressure chamber. A suspension of a small amount of $\mathrm{CuCl}$ in toluene $(1 \mathrm{~mL})$ was added and the channel was rinsed with of toluene $(1 \mathrm{~mL})$ Ethylene pressure ( 65 bar) was applied and the solution was stirred overnight at $40^{\circ} \mathrm{C}$, after which time the yellow color had paled. The solution was removed from the chamber; the solvent was evaporated, and the light brown residue was purified by chromatography and sublimation to give a white solid $(50 \mathrm{mg}, 0.13 \mathrm{mmol}, 74 \%) .{ }^{1} \mathrm{H} \mathrm{NMR}\left(\mathrm{CDCl}_{3}\right): \delta=1.38$ $\left(\mathrm{d},{ }^{2} J_{\mathrm{HP}}=7.5 \mathrm{~Hz}, 3 \mathrm{H} ; \mathrm{PMe}\right), 1.09-1.35\left(\mathrm{~m}, 4 \mathrm{H} ; \mathrm{CH}_{2}\right) ;{ }^{13} \mathrm{C} \mathrm{NMR}\left(\mathrm{CDCl}_{3}\right)$ : $\delta=196.0\left(\mathrm{~d},{ }^{2} J_{\mathrm{CP}}=8.4 \mathrm{~Hz}, \mathrm{CO}_{\mathrm{eq}}\right), 17.3\left(\mathrm{~d},{ }^{1} J_{\mathrm{CP}}=15.8 \mathrm{~Hz}, \mathrm{PMe}\right), 9.1 \mathrm{ppm}$ $\left(\mathrm{d},{ }^{1} J_{\mathrm{CP}}=10.8 \mathrm{~Hz}, \mathrm{CH}_{2}\right), \mathrm{CO}_{\mathrm{ax}}$ could not be observed; ${ }^{31} \mathrm{P} \mathrm{NMR}\left(\mathrm{CDCl}_{3}\right)$ : $\delta=-199.3 \mathrm{ppm}\left({ }^{1} J_{\mathrm{PW}}=254.1 \mathrm{~Hz}\right) ; \mathrm{IR}(\mathrm{KBr}): \bar{v}=2074.3\left(\mathrm{~m}, \mathrm{CO}_{\mathrm{ax}}\right), 1929.7$ $\left(\mathrm{s}, \mathrm{CO}_{\mathrm{eq}}\right), 1101.3(\mathrm{w}), 1023.2(\mathrm{w}), 948.0(\mathrm{w}), 597.9(\mathrm{w}), 572.8 \mathrm{~cm}^{-1}(\mathrm{w})$; HR-MS: calcd for $\mathrm{C}_{8} \mathrm{H}_{7} \mathrm{PO}_{5} \mathrm{~W}$ : 397.95410; found: $397.95462 ; \mathrm{m} / \mathrm{z}(\%)$ : $398(45)[M]^{+}, 370(8)[M-\mathrm{CO}]^{+}, 286(100)[M-4 \mathrm{CO}]^{+}, 256(76), 228$ (56), 43 (86)

Methylene addition to 9: Diethylzinc $(2.48 \mathrm{~mL}, 2.48 \mathrm{mmol})$ was added to $9(100 \mu \mathrm{L}, 495 \mu \mathrm{mol})$ in hexane $(10 \mathrm{~mL})$ at $0^{\circ} \mathrm{C}$. Diiodomethane $(166 \mu \mathrm{L}$, $1.98 \mathrm{mmol}$ ) was added dropwise under formation of a white precipitate. The mixture was warmed to $45^{\circ} \mathrm{C}$ for 3 days, then purified by extraction with an aqueous saturated ammonium chloride solution. GC-MS analysis (injector $140^{\circ} \mathrm{C}$; oven $40-230^{\circ} \mathrm{C}$ at $5-14.5 \mathrm{~min}$ ) showed no trace of the starting material. A mixture of mono- and bis-adduct $(3: 1)$ was obtained 
as a colorless oil $(76 \mathrm{mg}, 85 \%)$. The spectroscopic data of the adducts are consistent with those reported in the literature. ${ }^{[10 \mathrm{a}, \mathrm{c}]}$

Mono-adduct 5 a: ${ }^{1} \mathrm{H}$ NMR $\left(250.1 \mathrm{MHz}, \mathrm{CDCl}_{3}\right): \delta=1.62(\mathrm{~s}, 6 \mathrm{H} ;=\mathrm{CMe})$, 1.08 (s, 6 H; $\mathrm{CH}_{2} \mathrm{CMe}$ ), 0.80 (s, 6H; $\mathrm{CH}_{2} \mathrm{CCMe}$ ), 0.89, $0.25 \mathrm{ppm}(\mathrm{d}, 2 \mathrm{H}$; $\left.{ }^{2} J_{\mathrm{HH}}=-4.3 \mathrm{~Hz}, \mathrm{CH}_{2}\right) ;{ }^{13} \mathrm{C}\left\{{ }^{1} \mathrm{H}\right\} \mathrm{NMR}\left(62.9 \mathrm{MHz}, \mathrm{CDCl}_{3}\right): \delta=143.3(=\mathrm{C})$,

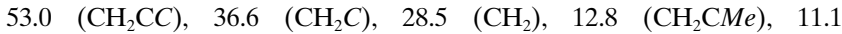
$\left(\mathrm{CH}_{2} \mathrm{CCMe}\right), 10.3 \mathrm{ppm}(=\mathrm{CMe}) ; \mathrm{GC}-\mathrm{MS}(t=12.75 \mathrm{~min}) \mathrm{m} / \mathrm{z}(\%): 176(4)$ $[M]^{+}, 161(100)[M-\mathrm{Me}]^{+}, 146(8)[M-2 \mathrm{Me}]^{+}, 133$ (39), 119 (41), 107 (52), 105 (39), 91 (49), 79 (17), 77 (24), 65 (12), 63 (7), 53 (16), 51 (13), 41 (23), 39 (35).

Bis-adduct $\quad 6 \mathbf{a}:{ }^{1} \mathrm{H} N M R \quad\left(250.1 \mathrm{MHz}, \quad \mathrm{CDCl}_{3}\right): \delta=1.30 \quad(\mathrm{~s}, \quad 12 \mathrm{H}$; $\mathrm{CH}_{2} \mathrm{CMe}$ ), 0.64 (s, 6H; $\left.\mathrm{CH}_{2} \mathrm{CCMe}\right), 0.54,-0.15 \mathrm{ppm}\left(\mathrm{d}, 4 \mathrm{H} ;{ }^{2} J_{\mathrm{HH}}=\right.$ $\left.-3.6 \mathrm{~Hz}, \mathrm{CH}_{2}\right) ;{ }^{13} \mathrm{C}\left\{{ }^{1} \mathrm{H}\right\} \mathrm{NMR}\left(62.9 \mathrm{MHz}, \mathrm{CDCl}_{3}\right): \delta=52.1\left(\mathrm{CH}_{2} \mathrm{CC}\right), 32.3$ $\left(\mathrm{CH}_{2} \mathrm{C}\right), 27.3\left(\mathrm{CH}_{2}\right), 13.5\left(\mathrm{CH}_{2} \mathrm{CMe}\right), 11.4 \mathrm{ppm}\left(\mathrm{CH}_{2} \mathrm{CCMe}\right) ; \mathrm{GC}-\mathrm{MS}$ $(t=14 \mathrm{~min}) \mathrm{m} / \mathrm{z}(\%): 190(1)[M]^{+}, 175[M-\mathrm{Me}]^{+}, 161(11), 147$ (31), 133 (100), 119 (67), 105 (50), 93 (17), 91 (61), 79 (24), 77 (31), 67 (11), 65 (15), 53 (26), 41 (41), 39 (45).

Attempted phosphinidene addition to $4 \mathbf{a}$ : Compounds 10a $(17.04 \mathrm{mg}, 30.4 \mu \mathrm{mol})$ and $(Z)-4 \mathbf{a}(14.63 \mathrm{mg}, 24.6 \mu \mathrm{mol})$ were dissolved in toluene $(0.50 \mathrm{~mL})$ and heated to $65^{\circ} \mathrm{C}$ for $3 \mathrm{~h} .{ }^{31} \mathrm{P}$ NMR spectroscopy showed only unreacted (Z)-4a and decomposition products of $\mathbf{1 0} \mathbf{a}$ at $\delta=$ -7.2 and $-119.9(\mathrm{~d}, J=11.8 \mathrm{~Hz}),-8.7$ and $-128.2(\mathrm{~d}, J=14.3 \mathrm{~Hz}),-15.9$ and $-123.7 \mathrm{ppm}(\mathrm{d}, J=11.5 \mathrm{~Hz}) .^{[14 \mathrm{~b}]}$

Attempted phosphinidene addition to $4 \mathrm{~b}$ : Compounds $10 \mathrm{~b}(12.43 \mathrm{mg}$, $25.0 \mu \mathrm{mol})$ and $\mathbf{4 b}(14.27 \mathrm{mg}, 26.8 \mu \mathrm{mol})$ were dissolved in toluene $(0.50 \mathrm{~mL})$, and heated to $75^{\circ} \mathrm{C}$ for $3 \mathrm{~h} .{ }^{31} \mathrm{P}$ NMR spectroscopy showed only unreacted $\mathbf{4 b}$ and signals at $\delta=-22.7$ and $-127.4(\mathrm{~d}, J=13.7 \mathrm{~Hz})$, -25.0 and $-152.4 \mathrm{ppm}(\mathrm{d}, J=14.5 \mathrm{~Hz})$, which we ascribed to the decomposition products of $\mathbf{1 0 b}$ analogous to $\mathbf{1 0} \mathbf{a}^{[14 \mathrm{~b}]}$

Attempted methylene addition to $4 \mathrm{a}$ : Diethylzinc $(0.10 \mathrm{~mL}, 100 \mu \mathrm{mol})$ was added to $(Z)-\mathbf{4 a}(11.95 \mathrm{mg}, 20.1 \mu \mathrm{mol})$ in hexane $(1.0 \mathrm{~mL})$ at $0{ }^{\circ} \mathrm{C}$. Diiodomethane $(6.6 \mu \mathrm{L}, 81.6 \mu \mathrm{mol})$ was added slowly under the formation of a white precipitate. The mixture was stirred at $25^{\circ} \mathrm{C}$ for one week, then purified by using an aqueous saturated ammonium chloride solution. ${ }^{31} \mathrm{P}$ and ${ }^{1} \mathrm{H}$ NMR spectroscopy showed only unreacted $(Z)-\mathbf{4 a}$.

Epoxidation of $4 \mathbf{a}$ : MCPBA $(10 \mathrm{mg}, 41 \mu \mathrm{mol})$ in DCM $(3 \mathrm{~mL})$ was dried over magnesium sulfate, filtered, and added dropwise to a solution of (Z)-4a $(7.8 \mathrm{mg}, 13 \mu \mathrm{mol})$ in DCM $(2 \mathrm{~mL})$ at $0^{\circ} \mathrm{C}$. After $15 \mathrm{~min}$, the mixture was stirred for $30 \mathrm{~min}$ at $25^{\circ} \mathrm{C}$. The modest stability of the $\mathrm{W}(\mathrm{CO})_{5}$ moiety in DCM precludes extensive reaction times. After evaporation, the faintly yellow residue was redissolved in pentane and washed five times with water $(\approx 3 \mathrm{~mL})$. Evaporation of the solvent afforded a white solid $(6.9 \mathrm{mg})$, which consisted of $47 \%$ unreacted $(Z)-\mathbf{4 a}, 42 \% \mathbf{1 8}$, and $11 \%$ of an unidentified byproduct at $\delta_{\mathrm{P}}=45.8 \mathrm{ppm}$. Data for compound 18: ${ }^{1} \mathrm{H}$ NMR $\left(400.1 \mathrm{MHz}, \mathrm{C}_{6} \mathrm{D}_{6}\right): \delta=7.28\left(\mathrm{ddd},{ }^{3} J_{\mathrm{HP}}=10.9,{ }^{3} J_{\mathrm{HH}}=7.4\right.$, $\left.{ }^{4} J_{\mathrm{HH}}=1.9 \mathrm{~Hz}, 2 \mathrm{H} ; o-\mathrm{PhH}\right), 6.89-6.82(\mathrm{~m}, 3 \mathrm{H} ; \mathrm{m} / \mathrm{p}-\mathrm{PhH}), 1.42\left(\mathrm{~d},{ }^{3} J_{\mathrm{HP}}=\right.$ 17.2 Hz, 6H; PCMe), 1.28 (s, 6H; OCMe), 0.76 ppm (s, 6H; PCCMe); ${ }^{13} \mathrm{C}\left[{ }^{1} \mathrm{H}\right\}$ NMR $\left(100.6 \mathrm{MHz}, \mathrm{C}_{6} \mathrm{D}_{6}\right): \delta=196.7\left(\mathrm{~d},{ }^{2} J_{\mathrm{CP}}=8.0 \mathrm{~Hz}, \mathrm{CO}_{\mathrm{eq}}\right), 137.3$ $\left(\mathrm{d},{ }^{1} J_{\mathrm{CP}}=17.6 \mathrm{~Hz}\right.$, ipso-Ph), $133.3\left(\mathrm{~d},{ }^{2} J_{\mathrm{CP}}=11.8 \mathrm{~Hz}, o-\mathrm{Ph}\right), 130.0\left(\mathrm{~d},{ }^{4} J_{\mathrm{CP}}=\right.$ $2.0 \mathrm{~Hz}, p-\mathrm{Ph}), 127.9(\mathrm{~m}-\mathrm{Ph}$, buried under the solvent signal), 73.1 (d, ${ }^{3} J_{\mathrm{CP}}=5.9 \mathrm{~Hz}$, OC), $60.6\left(\mathrm{~d},{ }^{2} J_{\mathrm{CP}}=7.3 \mathrm{~Hz}, \mathrm{PCC}\right), 45.2\left(\mathrm{~d},{ }^{1} J_{\mathrm{CP}}=16.3 \mathrm{~Hz}\right.$, PC), $16.0\left(\mathrm{~d},{ }^{2} J_{\mathrm{CP}}=10.7 \mathrm{~Hz}, \mathrm{PCMe}\right), 11.8(\mathrm{~s}, \mathrm{OCMe}), 11.3 \mathrm{ppm}\left(\mathrm{d},{ }^{3} J_{\mathrm{CP}}=\right.$ $3.4 \mathrm{~Hz}, \mathrm{PCCM}), \mathrm{CO}_{\mathrm{ax}}$ could not be observed; ${ }^{31} \mathrm{P}\left\{{ }^{1} \mathrm{H}\right\} \mathrm{NMR}(101.3 \mathrm{MHz}$, $\left.\mathrm{C}_{6} \mathrm{D}_{6}\right): \delta=-69.9 \mathrm{ppm}\left({ }^{1} J_{\mathrm{PW}}=260.1 \mathrm{~Hz}\right)$; HR-MS: calcd for $\mathrm{C}_{23} \mathrm{H}_{23} \mathrm{O}_{6} \mathrm{PW}$ : 610.0742; found: 610.0712 .

Crystal data for $(\boldsymbol{Z})-4 \mathrm{a}: \mathrm{C}_{23} \mathrm{H}_{23} \mathrm{O}_{5} \mathrm{PW}, M_{\mathrm{r}}=594.23$, colorless needle, $0.48 \times$ $0.18 \times 0.03 \mathrm{~mm}$, triclinic, $P \overline{1}$ (no. 2), $a=7.62343(14), b=11.8399(3), c=$ 13.0811(3) ̊ $, \quad \alpha=77.816(1), \quad \beta=82.605(1), \quad \gamma=85.718(1)^{\circ}, \quad V=$ 1143.14(4) $\AA^{3}, Z=2, \rho_{\text {calcd }}=1.726 \mathrm{~g} \mathrm{~cm}^{-3}, \mu=5.15 \mathrm{~mm}^{-1} .25262$ reflections were measured on a Nonius KappaCCD diffractometer with rotating anode (graphite monochromator, $\lambda=0.71073 \AA$ ) up to a resolution of $(\sin \theta / \lambda)_{\max }=0.65 \AA^{-1}$ at a temperature of $150 \mathrm{~K}$. Intensities were integrated with EvalCCD ${ }^{[37]}$ by using an accurate description of the experimental setup for the prediction of the reflection contours. An absorption correction based on multiple measured reflections was applied using the program SADABS ${ }^{[38]}(0.44-0.86$ correction range). 5230 reflections were unique $\left(R_{\text {int }}=0.0285\right)$. The structure was solved with the program DIRDIF-99 ${ }^{[39]}$ using automated Patterson Methods and refined with
SHELXL-97 ${ }^{[40]}$ against $F^{2}$ of all reflections. Non-hydrogen atoms were refined with anisotropic displacement parameters. All hydrogen atoms were introduced in calculated positions and refined with a riding model. 277 parameters were refined with no restraints. $R 1 / w R 2[I>2 \sigma(I)]$ $0.0190 / 0.0407$. $R 1 / w R 2$ (all data): 0.0228/0.0419. $S=1.040$. Residual electron density between -1.17 and $1.77 \mathrm{e}^{-3}$. Molecular illustration, geometry calculations, and checking for higher symmetry were performed with the PLATON program. ${ }^{[41]}$ CCDC 636374 contains the supplementary crystallographic data for this paper. These data can be obtained free of charge from The Cambridge Crystallographic Data Centre via www.ccdc.cam.ac.uk/data_request/cif..

\section{Acknowledgement}

This work was supported by the Netherlands Organization for Scientific Research, Chemical Sciences (NWO-CW). We acknowledge the National Center for Computing Facilities (SARA) and NWO/NCF for computer time. We thank Dr. M. Smoluch for measuring the high-resolution mass spectra and Ing. T. Nijbacker for the synthesis of phosphirane $\mathbf{1 2} \mathbf{b}$. We are indebted to one of the referees for constructive comments.

[1] a) T. T. Derencsényi, Inorg. Chem. 1981, 20, 665-670; b) M. Ackermann, A. Pascariu, T. Höcher, H.-U. Siehl, S. Berger, J. Am. Chem. Soc. 2006, 128, 8434-8440.

[2] a) A. Dransfeld, P. von R. Schleyer, Magn. Reson. Chem. 1998, 36, S29-S43; b) L. D. Quin, A Guide to Organophosphorus Chemistry, Wiley, New York, 2000, chapter 6, pp. 169-203.

[3] a) L. D. Quin, K. C. Caster, J. C. Kisalus, K. A. Mesch, J. Am. Chem. Soc. 1984, 106, 7021-7032; b) E. Lindner, R. Fawzi, H. A. Mayer, K Eichele, W. Hiller, Organometallics 1992, 11, 1033-1043; c) L. D. Quin, G. Keglevich, A. S. Ionkin, R. Kalgutkar, G. Szalontai, J. Org. Chem. 1996, 61, 7801-7807.

[4] a) D. B. Chesnut, L. D. Quin, K. D. Moore, J. Am. Chem. Soc. 1993, 115, 11984-11990; b) D. B. Chesnut, Chem. Phys. 1997, 224, $133-$ 141; c) D. B. Chesnut, L. D. Quin, S. B. Wild, Heteroat. Chem. 1997 $8,451-457$; d) D. B. Chesnut, L. D. Quin, Heteroat. Chem. 1999, 10, $566-572$.

[5] a) Y. Ruiz-Morales, T. Ziegler, J. Phys. Chem. A 1998, 102, 39703976; b) G. M. Bernard, G. Wu, M. D. Lumsden, R. E. Wasylishen, N. Maigrot, C. Charrier, F. Mathey, J. Phys. Chem. A 1999, 103, 1029-1037; c) C. van Wüllen, Phys. Chem. Chem. Phys. 2000, 2, 2137-2144; d) K. W. Feindel, R. E. Wasylishen, Can. J. Chem. 2004, $82,27-44$.

[6] a) F. Mathey, Angew. Chem. 1987, 99, 285-296; Angew. Chem. Int. Ed. Engl. 1987, 26, 275-286; b) Multiple Bonds and Low Coordination in Phosphorus Chemistry (Eds.: M. Regitz, O. J. Scherer), Thieme, Stuttgart, 1991; c) K. B. Dillon, F. Mathey, J. F. Nixon, Phosphorus: The Carbon Copy, Wiley, New York, 1998; d) F. Mathey, N. H. T. Huy, A. Marinetti, Helv. Chim. Acta 2001, 84, 2938-2957; e) K. Lammertsma, M. J. M. Vlaar, Eur. J. Org. Chem. 2002, 1127-1138; f) K. Lammertsma, Top. Curr. Chem. 2003, 229, 95-119.

[7] J.-T. Hung, P. Chand, F. R. Fronczek, S. F. Watkins, K. Lammertsma, Organometallics 1993, 12, 1401-1405.

[8] J. C. Slootweg, S. Krill, F. J. J. de Kanter, M. Schakel, A. W. Ehlers, M. Lutz, A. L. Spek, K. Lammertsma, Angew. Chem. 2005, 117, 6737-6740; Angew. Chem. Int. Ed. 2005, 44, 6579-6582.

[9] a) M. J. M. Vlaar, M. H. Lor, A. W. Ehlers, M. Schakel, M. Lutz, A. L. Spek, K. Lammertsma, J. Org. Chem. 2002, 67, 2485-2493; b) J. C. Slootweg, F. J. J. de Kanter, M. Schakel, A. W. Ehlers, S. I. Kozhushkov, A. de Meijere, M. Lutz, A. L. Spek, K. Lammertsma, J. Am. Chem. Soc. 2004, 126, 3050-3051; c) J. C. Slootweg, F. J. J. de Kanter, M. Schakel, M. Lutz, A. L. Spek, S. I. Kozhushkov, A. de Meijere, K. Lammertsma, Chem. Eur. J. 2005, 11, 6982-6993. 
[10] a) E. Müller, H. Kessler, Tetrahedron Lett. 1968, 9, 3037-3040; b) H. Prinzbach, E. Druckrey, Tetrahedron Lett. 1968, 9, 4285-4288; c) S. D. Reilly, C. C. Wamser, J. Org. Chem. 1991, 56, 5232-5234.

[11] a) T. G. Traylor, A. R. Miksztal, J. Am. Chem. Soc. 1987, 109, 2270 2274; b) A. Dunand, R. Gerdil, Acta Crystallogr. Sect. B 1980, 36, $472-474$; c) A. Asouti, L. P. Hadjiarapoglou, Tetrahedron Lett. 2000 , $41,539-542$.

[12] M. G. Barlow, R. N. Haszeldine, W. D. Morton, D. R. Woodward, J. Chem. Soc. Perkin Trans. 1 1973, 1798-1802.

[13] J. M. Bolster, H. Hogeveen, R. M. Kellogg, L. Zwart, J. Am. Chem. Soc. 1981, 103, 3955-3956.

[14] a) M. L. G. Borst, R. E. Bulo, C. Winkel, D. J. Gibney, A. W. Ehlers, M. Schakel, M. Lutz, A. L. Spek, K. Lammertsma, J. Am. Chem. Soc. 2005, 127, 5800-5801; b) M. L. G. Borst, R. E. Bulo, D. J. Gibney, Y. Alem, F. J. J. de Kanter, A. W. Ehlers, M. Schakel, M. Lutz, A. L. Spek, K. Lammertsma, J. Am. Chem. Soc. 2005, 127, 16985-16999.

[15] We have adopted the numbering scheme from the crystal structure of $(Z)-\mathbf{4 a}$ in Figure 2, rather than the formal numbering for fused ring systems.

[16] a) See: T. T. Tidwell, T. G. Traylor, J. Org. Chem. 1968, 33, 2614 2620, and references therein; b) S. Inagaki, H. Fujimoto, K. Fukui, J. Am. Chem. Soc. 1976, 98, 4054-4061; c) R. Huisgen, P. H. J. Ooms, M. Mingin, N. L. Allinger, J. Am. Chem. Soc. 1980, 102, 3951-3953.

[17] a) N. H. T. Huy, F. Mathey, Phosphorus Sulfur Silicon Relat. Elem. 1990, 47, 477-481; b) J.-T. Hung, S.-W. Yang, G. M. Gray, K. Lammertsma, J. Org. Chem. 1993, 58, 6786-6790.

[18] M. L. G. Borst, Generating Phosphinidenes: New Approaches, PhD Thesis, Vrije Universiteit, Amsterdam (The Netherlands), 2005, Chapter 2.

[19] J.-T. Hung, S.-W. Yang, P. Chand, G. M. Gray, K. Lammertsma, J. Am. Chem. Soc. 1994, 116, 10966-10971.

[20] a) H. Irngartinger, T. Oeser, R. Jahn, D. Kallfass, Chem. Ber. 1992, 125, 2067-2073; b) R. Gleiter, F. Ohlbach, T. Oeser, H. Irngartinger, Liebigs Ann. 1996, 785-790.

[21] The acute interplanar angles of the central cyclobutane ring with the phosphirane and the cyclobutene ring are $61.43(19)^{\circ}$ and $69.78(19)^{\circ}$, respectively. C9 and C12 make acute interplanar angles of $49.6(2)^{\circ}$ with the central cyclobutane and $60.7(2)^{\circ}$ with the cyclobutene ring.

[22] a) "Chemistry with ADF": G. te Velde, F. M. Bickelhaupt, E. J. Baerends, C. Fonseca Guerra, S. J. A. van Gisbergen, J. G. Snijders, T. Ziegler, J. Comput. Chem. 2001, 22, 931-967; b) C. Fonseca Guerra, J. G. Snijders, G. te Velde, E. J. Baerends, Theor. Chem. Acc. 1998, 99, 391-403; c) ADF2004.01, SCM, Theoretical Chemistry, Vrije Universiteit, Amsterdam (The Netherlands), http:// www.scm.com

[23] Calculation of NMR and EPR Parameters-Theory and Applications (Eds: M. Kaupp, M. Bühl, V. G. Malkin), Wiley-VCH, Weinheim, 2004.

[24] a) P. George, M. Trachtman, C. W. Bock, A. M. Brett, Tetrahedron 1976, 32, 317-323; b) T. P. M. Goumans, A. W. Ehlers, K. Lammertsma in Encyclopedia of Computational Chemistry (Ed: P. von R. Schleyer), Wiley, New York, 2004, published on the web (http:// www.mrw.interscience.wiley.com/ecc/articles/cn0067/frame.html); c) M. L. G. Borst, A. W. Ehlers, K. Lammertsma, J. Org. Chem. 2005, 70, 8110-8116.

[25] Gaussian 03 (Revisions B.05 and C.02), M. J. Frisch, G. W. Trucks, H. B. Schlegel, G. E. Scuseria, M. A. Robb, J. R. Cheeseman, J. A. Montgomery, Jr., T. Vreven, K. N. Kudin, J. C. Burant, J. M. Millam, S. S. Iyengar, J. Tomasi, V. Barone, B. Mennucci, M. Cossi, G. Scalmani, N. Rega, G. A. Petersson, H. Nakatsuji, M. Hada, M. Ehara, K. Toyota, R. Fukuda, J. Hasegawa, M. Ishida, T. Nakajima, Y.
Honda, O. Kitao, H. Nakai, M. Klene, X. Li, J. E. Knox, H. P. Hratchian, J. B. Cross, V. Bakken, C. Adamo, J. Jaramillo, R. Gomperts, R. E. Stratmann, O. Yazyev, A. J. Austin, R. Cammi, C. Pomelli, J. W. Ochterski, P. Y. Ayala, K. Morokuma, G. A. Voth, P. Salvador, J. J. Dannenberg, V. G. Zakrzewski, S. Dapprich, A. D. Daniels, M. C. Strain, O. Farkas, D. K. Malick, A. D. Rabuck, K. Raghavachari, J. B. Foresman, J. V. Ortiz, Q. Cui, A. G. Baboul, S. Clifford, J. Cioslowski, B. B. Stefanov, G. Liu, A. Liashenko, P. Piskorz, I. Komaromi, R. L. Martin, D. J. Fox, T. Keith, M. A. Al-Laham, C. Y. Peng, A. Nanayakkara, M. Challacombe, P. M. W. Gill, B. Johnson, W. Chen, M. W. Wong, C. Gonzalez, J. A. Pople, Gaussian, Inc., Wallingford CT, 2004.

[26] A. G. Baboul, L. A. Curtiss, P. C. Redfern, J. Chem. Phys. 1999, 110, $7650-7657$.

[27] a) J. F. M. Oth, Recl. Trav. Chim. Pays-Bas 1968, 87, 1185-1195; b) W. Adam, J. C. Chang, Int. J. Chem. Kinet. 1969, 1, 487-492.

[28] Olefin strain is defined as the difference in total strain energy between a cyclic olefin and its hydrogenated counterpart, both in their most stable conformation: W. F. Maier, P. von R. Schleyer, J. Am. Chem. Soc. 1981, 103, 1891-1900; exo--exo hydrogenation of HMDB yields an olefin strain of $4.2 \mathrm{kcal} \mathrm{mol}^{-1}$.

[29] M. J. M. Vlaar, A. W. Ehlers, F. J. J. de Kanter, M. Schakel, A. L. Spek, K. Lammertsma, Angew. Chem. 2000, 112, 3071-3074; Angew. Chem. Int. Ed. 2000, 39, 2943-2945.

[30] a) A. Marinetti, F. Mathey, Organometallics 1984, 3, 456-461; b) A Marinetti, F. Mathey, J. Fischer, A. Mitschler, J. Am. Chem. Soc. 1982, 104, 4484-4485; c) A. Marinetti, F. Mathey, Organometallics 1982, $1,1488-1492$.

[31] a) A. Marinetti, C. Charrier, F. Mathey, J. Fischer, Organometallics 1985, 4, 2134-2138; b) N. H. T. Huy, Y. Inubushi, L. Ricard, F. Mathey, Organometallics 1997, 16, 2506-2508.

[32] K. Lammertsma, A. W. Ehlers, M. L. McKee, J. Am. Chem. Soc. 2003, $125,14750-14759$.

[33] The aromatization of HMDB (9) to hexamethylbenzene is thermally forbidden, and the half-life of 9 is more than $21 \mathrm{~h}$ at $120^{\circ} \mathrm{C}$ : W. J. le Noble, K. R. Brower, C. Brower, S. Chang, J. Am. Chem. Soc. 1982 104, 3150-3152. Thus, the phosphinidene precursor 16 can be used at $110^{\circ} \mathrm{C}$ without a catalyst, which precludes diphosphene formation.

[34] a) J. Furukawa, N. Kawabata, J. Nishimura, Tetrahedron 1968, 24, 53-58; b) I. Arai, A. Mori, H. Yamamoto, J. Am. Chem. Soc. 1985 $107,8254-8256$.

[35] Conversion after $45 \mathrm{~min} ; 47 \%$ starting material was still present. The modest stability of the $\mathrm{W}(\mathrm{CO})_{5}$ moiety in DCM precludes extensive reaction times.

[36] H. E. Gottlieb, V. Kotlyar, A. Nudelman, J. Org. Chem. 1997, 62, $7512-7515$.

[37] A. J. M. Duisenberg, L. M. J. Kroon-Batenburg, A. M. M. Schreurs, J. Appl. Crystallogr. 2003, 36, 220-229.

[38] G. M. Sheldrick, SADABS: Area-Detector Absorption Correction, v2.10, Universität Göttingen, Göttingen (Germany), 1999

[39] P. T. Beurskens, G. Admiraal, G. Beurskens, W. P. Bosman, S. Garcia-Granda, R. O. Gould, J. M. M. Smits, C. Smykalla, The DIRDIF99 program system, Technical Report of the Crystallography Laboratory, University of Nijmegen, Nijmegen (The Netherlands), 1999.

[40] G. M. Sheldrick, SHELXL-97: Program for crystal structure refinement, Universität Göttingen, Göttingen (Germany), 1997.

[41] A. L. Spek, J. Appl. Crystallogr. 2003, 36, 7-13.

Received: June 22, 2007 Published online: November 21, 2007 